\title{
Debris flow triggering characterization through a comparative analysis among different mountain catchments
}

\author{
Roberta Pastorello ${ }^{\mathrm{a}}$, Vincenzo D'Agostino ${ }^{\mathrm{a}}$, Marcel Hürlimann ${ }^{\mathrm{b}}$ \\ ${ }^{a}$ Department TeSAF, University of Padova Viale dell'Università 16, 35020, Legnaro (PD), Italy \\ ${ }^{b}$ Divison of Geotechnical Engineering and Geosciences, Department of Civil and Environmental \\ Engineering, BarcelonaTECH (UPC), 08034, Barcelona, Spain
}

\begin{abstract}
The research focuses on the assessment of the conditions for debris flow triggering in three very active mountain catchments. The study areas are the following: Rudan torrent (Vodo di Cadore, Mount Antelao in the Dolomites, Italy), Chiesa torrent (Pieve di Livinallongo, Mount Col di Lana, in the Dolomites, Italy) and Rebaixader torrent (border between the regions of Catalonia and Aragon, Axial Pyrenees area, Spain). Thanks to the differences among these basins and related source areas where debris flows originate, the knowledge on the link between geomorphic conditions and driving mechanisms for debris flow activation is outlined. The study of debris flow initiation is carried out through a hydrological approach and a slope stability analysis. The hydrological analysis is supported by the calibration of intensity-duration curves of triggering rainfalls coupled with a distributed rainfall-runoff model. The analysis is corroborated using literature equations to compute critical discharges for sediment motion at the different levels of terrain deformation. Main results highlight: i) a quite narrow range of triggering water discharges $\left(0.03-0.16 \mathrm{~m}^{3} / \mathrm{s}\right)$ and shear stresses $\left(267-413 \mathrm{~N} / \mathrm{m}^{2}\right)$, promoting a new insight on the specific hazard mitigation, ii) the quantification of a
\end{abstract}

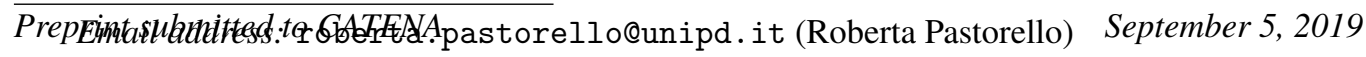


second stage of bed-breakage capable in some circumstances to amplfy the debris flow magnitude; iii) a minimum critical rainfall duration needed to effectively entrain the phenomenon (12-22 minutes) and that might help to define more precise alert conditions. Finally, the geomorphologic differences among basins revealed two main typologies in terms of driving triggering mode: flow rate dominant in the Rudan-type basins and mixed (flow rate plus slope stability conditioned) in the Chiesa-Rebaixader type basins.

Keywords: Debris flow initiation, Runoff, Headwater basin, Hydrological modelling

\section{Introduction}

Debris flows are mixed masses formed by rocks, mud, water and air that move with relatively rapid velocities inside steep channels in mountainous catchments [1]. This type of mass movement has become one of the most dangerous threats for alpine valleys $[2,3]$. Thanks to the general economic development of the last century [4], there has been a relevant expansion of human settlements in unstable mountainous areas. Therefore, studies on debris flows have become crucially important because of the economic and social losses that these phenomena can cause. In recent years, many studies have concentrated on the modelling of torrential flows $[5,6,7,8,9,10,11]$, giving particular importance to the triggering of debris flows events. The triggering mechanism is a complex phenomenon that depends on different variables. Many studies $[12,13]$ have reported that the three most important variables for the triggering of a debris flow are slope gradient, sediment availability $[14,15]$ and water input. Therefore, for a basin never limited by the first two variables, water input plays the most important role. There can 
be different types of water input, like for example outburst floods, or snow melt or rainfall events. In the present study we focused in particular on the last one because if the rainfall is strong enough, the water inside the channels can reach a critical discharge in which the mobilization of sediments starts $[16,17,18,19]$.

Considering the hydrological response of the catchment to precipitation, two main types of debris flow triggering events have been described: (1) channel-bed failure and (2) shallow slope failure.

1. The first type happens when a debris flow originates from an initial gully erosion that rapidly evolve in a massive erosion of both the channel bed and channel banks caused by a superficial runoff fast removing shallow layers mostly. In addition, [20] described a sub-type of channel-bed failure, which happens when the debris flow material is not derived from an erosional mechanism but is derived from the mobilization of previously accumulated loose debris inside the channel (dam-break mechanism). Such material moves because it is liquified and/or is overflown by erosive water discharge.

2. The second type happens when a shallow landslide caused by the rapid infiltration of water in the superficial soil layers develops in a debris flow. In fact, the subsurface water can partially saturate soil, taking the material near the critical stability conditions $[21,22,23,24]$ and destabilizing the nearsurface layers composed of less compact sediments. These types of terrain mobilization can evolve into debris flows if slope failure happens in a zone of the basin connected [25] to the channel network [2].

Therefore, to investigate in particular the first type of initiation mechanism, it can be useful to find the rainfall intensity and duration needed to reach the critical 
discharge inside the channel. For this purpose, the maximum rainfall intensityduration equations related to the triggering of torrential flows are particularly relevant. Precipitations with an intensity greater than the one described by these curves can potentially initiate sediment mobilization. Many studies carried out in the last few decades have proposed several rainfall thresholds based on different study areas $[26,27,28,29,30,31,32,33,34,35,36]$. Moreover, many studies have concentrated on the analysis of the critical water discharge needed for the in-channel mobilization of sediments $[37,38,19]$. Therefore, coupling these two approaches (intensity-duration equations and critical water discharge), we can achieve the following goals: (1) make significant improvements on understanding the conditions needed to trigger debris flows in real case study areas; (2) understand the link between the trigger type and respective most effective forcing. The advantage of this type of study is that we can estimate more precisely the critical rainfalls and related discharges in order to take correct decisions on the management of debris flow hazard, whereas the limitation is that the results depend on the quality of the topographic data and on the intensity-duration equation chosen. In the present work, we selected three different catchments: the Rudan torrent (Mount Antelao) and the Chiesa torrent (Col di Lana) in the Eastern Italian Alps and the Rebaixader torrent in the Spanish Axial Pyrenees. The catchments show different morphological and geological settings, and so their response to water input varies because the catchment morphology has a great influence on runoff initiation [39]. Therefore, it is relevant to study such different catchments because the comparison of their behavior is likely more instructive than a regional case study where the basin sample would be more homogeneous.

The main aim of this study is to verify how the triggering conditions may vary 
among basins with different geological and morphological conditions. In particular, we analyzed the following questions: (1) what is the minimum rainfall duration over a given threshold intensity that can generate a critical discharge inside the channel network? (2) What is the range of critical discharges that can trigger a channel-bed failure debris flow in the analyzed areas? (3) How relevant is the shallow-slope failure mechanism in the destabilization of the studied headwater basins and triggering areas?

\section{Study areas}

\subsection{The Rudan catchment}

The Rudan torrent is one of the main channels that flows down from the South side of Mount Antelao (3264 m a.s.l.) (Fig. 1). This torrent is located in the municipality of Vodo di Cadore (BL, North-Eastern Italy) and has an area of 2.71 $\mathrm{km}^{2}$. The channel starts just below the peak of the mountain, inside a great source area named "Vallon dell' Antelao", and flows down until confluence with the Boite torrent. The catchment has a wide elevation range from $3229 \mathrm{~m}$ a.s.1 to $788 \mathrm{~m}$ a.s.l [40]. The mean annual precipitation of the basin is $1130 \mathrm{~mm}$ and the mean number of rainy days per year is 110 (data collected between 1985 and 2018 by the meteorological station of ARPAV - Regional Agency for Environmental Prevention and Protection of Veneto - located in Borca di Cadore, BL - WGS84 coordinates: $12.2^{\circ} \mathrm{E}, 46.4^{\circ} \mathrm{N}$ ).

In the past, the catchment has experienced very strong torrential events. Historical documentation describes catastrophic debris flows that completely buried and destroyed ancient villages [41]. In addition, in the last decades, the catchment has suffered debris flows that damaged the municipality and the National Road 51 
"di Alemagna". For this reason, in 2011, a filter check-dam with a storage basin was built just above the street (Fig. 1). Mainly dolomitic rocks characterize the geology of the basin, especially in the upper part.

In the hydrological modelling area (Fig. 6), we analyzed the soil matrix, considering as "matrix" the finer part of the soil, excluding pebbles and boulders. In particular, we used the following classification: pebbles if the diameter is greater than $60 \mathrm{~mm}$; gravel when the diameter goes from 2 to $60 \mathrm{~mm}$; sand when the diameter goes from 0.075 to $2 \mathrm{~mm}$; silt when the diameter goes from 0.002 to 0.075 $\mathrm{mm}$ and clay when the diameter is finer than $0.002 \mathrm{~mm}$. The soil matrix in the source area of the Rudan catchment (triggering area shown in Fig. 1 and Fig. 6) is mainly composed of gravel and sand, whereas only a small percentage of the matrix is composed of finer material $(6.7 \%$, Fig. 2). Boulders and large cobbles are quite abundant, corresponding to an amount by volume of about $20 \%$ (resulting from Image Processing of a Vertical Trench IPVT of the source area entrainable material.

In the headwater basin, there are rock faces and talus slopes that continuously recharge the catchment with new sediment. For this reason, we can consider the Rudan torrent as a transport-limited system [14] in terms of sediment yield due to debris flows. The most important source of sediment is the area named "Vallon dell'Antelao" that is located between $2400 \mathrm{~m}$ a.s.l and $2000 \mathrm{~m}$ a.s.l (Fig. 1). This zone is characterized by the highest terrain slope between the three basins (Tab. 1) and is formed by a steep talus cone covered by loose debris, with a grain size that varies from silt to boulders of $5 \mathrm{~m}$ in size. This area is clearly an unlimited source of material, and the depth of the available sediment thickness has been evaluated as more than 20 meters [40]. 
Table 1: Main characteristics of the three hydrological modelling areas.

\begin{tabular}{lccc}
\hline & Rudan & Chiesa & Rebaixader \\
\hline Area $\left(\mathrm{km}^{2}\right)$ & 0.82 & 0.48 & 0.53 \\
Max Elevation (m a.s.l) & 3260 & 2503 & 2475 \\
Min Elevation (m a.s.l) & 1804 & 1692 & 1350 \\
Mean Elevation (m a.s.l) & 2507 & 2086 & 1738 \\
Average terrain slope $\left({ }^{\circ}\right)$ & 47 & 31 & 32 \\
Average channel slope $\left({ }^{\circ}\right)$ & 43 & 35 & 25 \\
\hline
\end{tabular}

\subsection{The Chiesa catchment}

Chiesa is a torrent that flows down the south side of Col di Lana (2452 m a.s.1.) (Fig. 3). This mountain is inside the dolomitic territory but is characterized by a different geology than that of the Rudan basin. The hydrological modelling area of this basin is the smallest between the three study areas $\left(0.48 \mathrm{~km}^{2}\right.$, Tab. 1$)$, whereas the total area of the catchment is of $1.15 \mathrm{~km}^{2}$ (red line in Fig. 3) with an elevation range between 1180 and $2450 \mathrm{~m}$ a.s.1.. The mean annual precipitation of the basin is $1080 \mathrm{~mm}$ and the mean number of rainy days per year is 114 (data collected between 1985 and 2018 by the meteorological station of ARPAV - Regional Agency for Environmental Prevention and Protection of Veneto - located in Arabba, BL - WGS84 coordinates: $\left.11.9^{\circ} \mathrm{E}, 46.5^{\circ} \mathrm{N}\right)$.

The main rock types consist of: (1) conglomerates, (2) volcanic rocks such as hyaloclastites and tufas (Fernazza formation) and (3), especially, in the lower part of the catchment, calciculites and limestones (Livinallongo formation) [42]. The soil composition in Chiesa basin is also different from that in the Rudan catchment. The soil matrix in the source area is composed by a silt percentage 


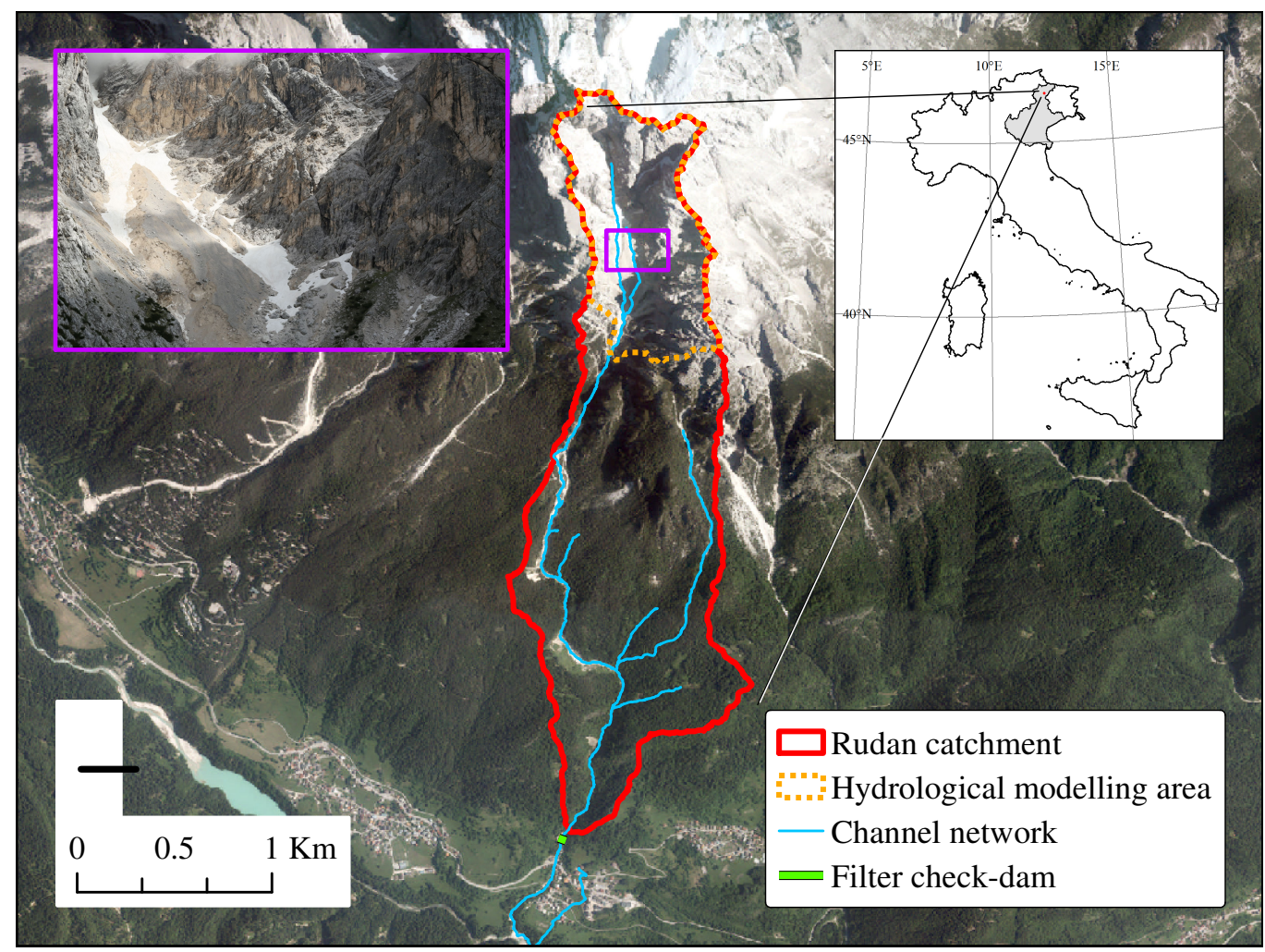

Figure 1: Map of the Rudan catchment with a zoom-in of the triggering area named "Vallon dell'Antelao".

of $22.6 \%$ and clay percentage of $9.4 \%$ (Fig. 2) thus, percentage of the finest soil component is higher than that of the gravel and sand component. The cobble and boulder presence is rare, being approximately equal to 5\% (resulting from IPVT). The main channel of the basin is the Chiesa torrent, which flows into the Cordevole torrent at $1175 \mathrm{~m}$ a.s.1., passing through the village of Pieve di Livinallongo (BL, North-Eastern Italy) (Fig. 3). Immediately upstream of the National Road 48 "Delle Dolomiti", there is a filter check-dam with a storage basin (Fig. $3)$.

The source areas where debris flows initiate are not surrounded by rock faces 


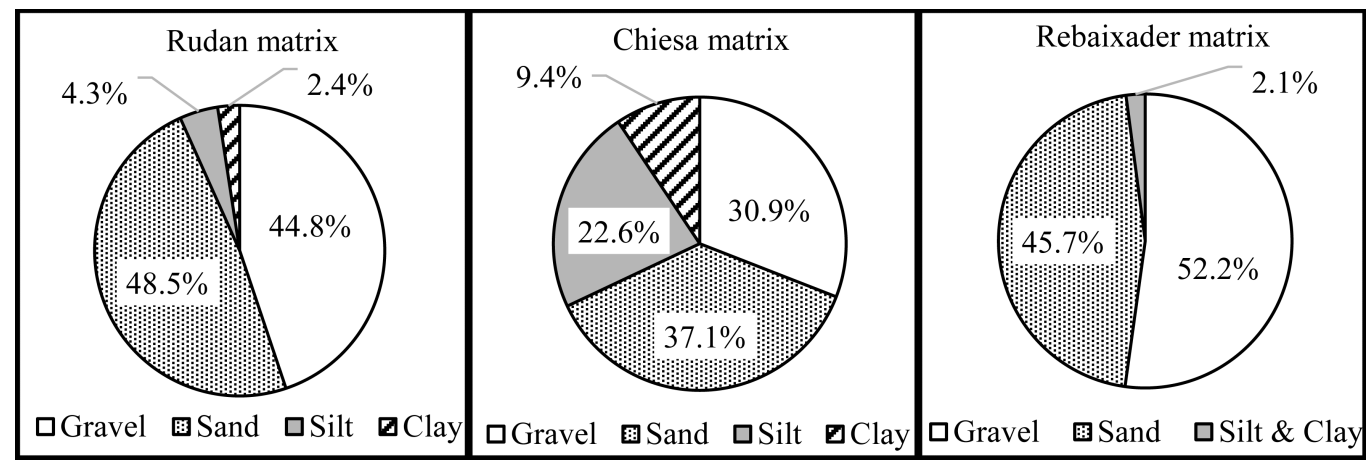

Figure 2: Grain size of the soil matrix in the three hydrological modelling areas.

like in the Rudan basin. These areas are parts (mostly flanks) of landslides under accelerated erosion with a high slope gradient (approximately $35-45^{\circ}$ ). Here, rocks and sediments emerge from a matrix mainly composed of silt and sand (Fig. 2). Moreover, these triggering zones are not located exactly in the upper part of the catchment but are at an elevation from 1800 to $2100 \mathrm{~m}$ a.s.l. Above this elevation there is a flat zone, which partly disconnects [25] the highest part of the catchment from the debris flow-triggering areas. Although the morphology of the Chiesa catchment differs from that of the Rudan basin, this catchment can be considered a transport-limited system [14]. In fact, the high slope gradient and the abundant sediment cover are not limiting factors for debris-flow triggering.

\subsection{The Rebaixader catchment}

This catchment is located in the Spanish Pyrenees, near the border between the regions of Catalonia and Aragon (Fig. 4). The headwater basin area is relatively small (Tab. 1) and has an elevation range between 1350 and $2475 \mathrm{~m}$ a.s.l.. Whereas, the total area of the catchment is $0.7 \mathrm{~km}^{2}$ with an elevation range between 1238 and $2298 \mathrm{~m}$ a.s.l.. The mean annual precipitation of the basin fluc- 


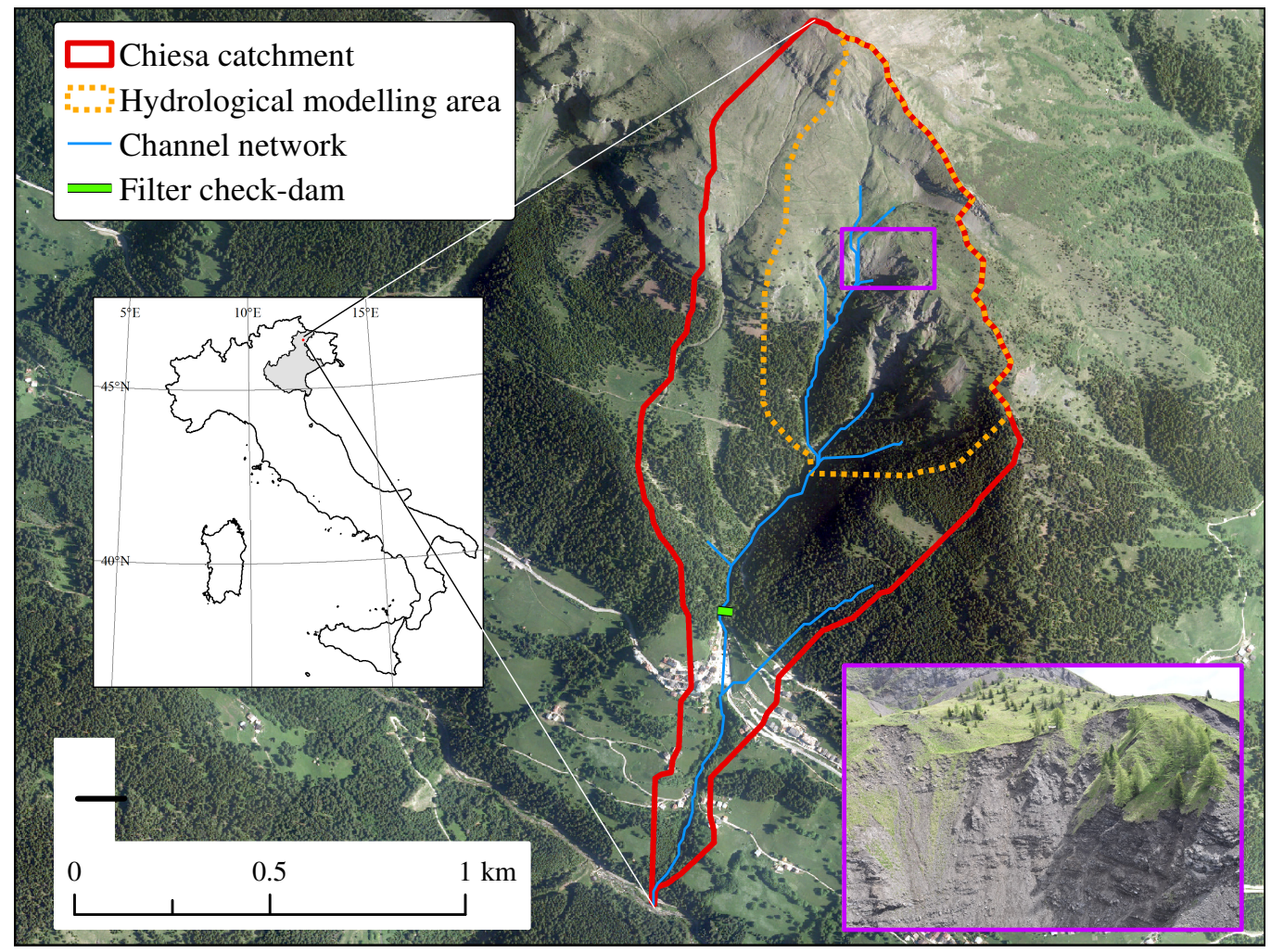

Figure 3: Map of the Chiesa catchment with a zoom-in of the source areas

tuates between $800 \mathrm{~mm}$ and $1200 \mathrm{~mm}$ [43] and the mean number of rainy days per year is 152 (data collected by the meteorological station installed inside the catchment in 2009).

The transport zone of the Rebaixader catchment is relatively short (100-150 $\mathrm{m}$ long, Fig. 4); the channel has a width of 8-10 $\mathrm{m}$ and a slope angle of $25^{\circ}$ (Tab. 1). In the lower part of the catchment, there is a small fan immediately before the intersection with the Noguera Ribagorçana River.

The debris-flow-triggering zone is a unique wide area characterized by a steep slope gradient $\left(32^{\circ}\right.$, Tab. 1) consisting of a lateral moraine with almost an un- 
limited sediment supply (Fig. 4). The geology of this source area is composed of metamorphic rocks; here, we can observe blocks of different dimensions, from clay and silt to randomly sparse small/large boulders (about $15 \%$ by volume according to IPVT). In this catchment, the composition of the matrix is similar to the composition of the Rudan catchment matrix, i.e., the most abundant components are gravel and sand, and only $2 \%$ of the matrix is silt and clay (Fig. 2). The estimated depth of this sediment cover reaches up to tens of meters [44]. For this reason, the catchment is often impacted by debris flow and debris flood events and was selected to host a monitoring station. The great activity of this region allows many data to be collected in a relatively short amount of time. The monitoring station was installed in 2009, and since then, more than 30 debris flow and flood events have been registered [45, 46, 36].

Similarly to the two other study areas, this catchment is a transport-limited system [14], i.e. the limiting factor is the water input, whereas the slope gradient and excess sediment recharge, with respect the debris flow generation, are always above the critical thresholds.

\section{Data and methods}

The analysis of the triggering phenomenon in the three study areas has been developed considering different triggering mechanisms. In particular, the two main triggering mechanisms described in the literature are channel bed failure and shallow slope failure [16]. We decided to distinguish between two more precise subdivisions of the first type of mechanism: progressive bed erosion, when the runoff generated by intense rainfall starts to erode the channel bed, and full bed breakage, when there is an overall collapse of the channel bed and banks involving 


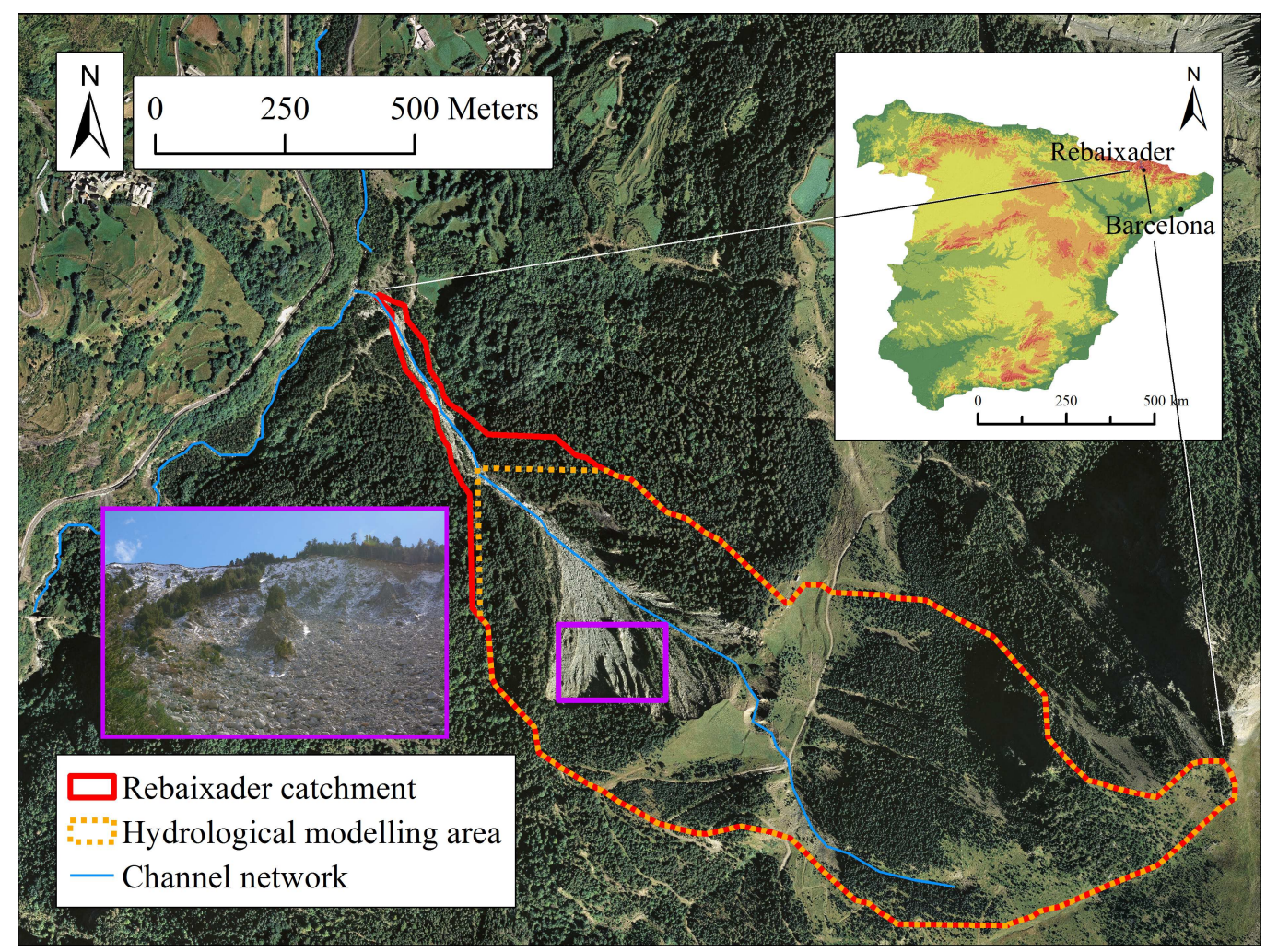

Figure 4: Map of the Rebaixader catchment with a zoom-in of the triggering area.

blocks of higher dimensions than the previous subdivision.

Therefore, we considered the following three triggering scenarios:

1. In-channel triggering due to progressive bed erosion

2. Channel-bed failure due to full bed breakage

3. Shallow slope failure.

In Fig. 5 is represented the flow chart of the methodology used to study the hydrology of the triggering areas, regarding in particular the first two scenarios. In every catchment, we selected three control cross-sections in which we verified at which conditions the critical discharge for the initiation of torrential flows was 
exceeded (Figs. 6-7-8). To compute the critical water discharges in the control cross-sections, for the first and second scenario, we used two different equations: the equation proposed by [19] for the progressive erosion of the channel bed, and the equation proposed by [47] for the bed breakage scenario. This second equation was developed to study the threshold destabilization slope of artificial blockramps (consolidation work built with boulders). The critical discharges obtained with the second equation likely correspond to more powerful and destructive debris flows after their initiation. The surges originating from these discharges have the possibility to mobilize and transport blocks and boulders of high dimensions even in the source area, leading to possible clogging mechanisms and deposit collapses (dam-breaks) inside the channels.

For the third scenario, we conducted a slope stability analysis in the triggering areas, using the geotechnical parameters of the soil to study the destabilization of the hillslope due to water infiltration.

Considering the Rudan torrent, we analyzed the headwater basin both in terms of hydrology and hillslope stability. Here, initiation zones are located at the foot of steep rock faces [19] and are usually characterized by a very high slope gradient and by the presence of loose and poorly cohesive debris that can be easily mobilized by running waters. In the two other basins the triggering areas are not properly located in the highest part of the catchment. In these cases the triggering areas have been analaysed (hydrology/hilloslope stability) considering the upslope contributing area.

\subsection{The hydrological approach}

The aim of this part of the analysis was to identify the critical rainfall duration related to the critical water discharge capable of mobilizing sediments, leading to 
the triggering of a debris flow. First, in the three study areas, the headwater basin and triggering areas of debris flow initiation were identified $[48,19]$.

In every hydrological modelling area (Fig. 1, Fig. 3 and Fig. 4), we selected, inside the triggering areas, three cross-sections: two cross-sections along the channel network and one cross-section in the corresponding outlet (Fig. 6, Fig. 7 and Fig. 8). The $x y$ coordinates of these sections and the thalweg slope in the surrounding reach were extracted from the DTM (digital terrain model) maps (DTM analysis in Fig. 5). In Fig. 6-7-8 it can be seen the morphology of the cross sections extracted from the DTM maps. The slope of the thalweg profile was calculated as the mean slope gradient in a close channel reach (cross-section in the intermediate position) with a length of $30 \mathrm{~m}$. To verify if the length used for the slope computation of the reach influences the slope values and consequently the critical discharge calculated with the selected equations, we also computed the mean slope for reaches $10 \mathrm{~m}$ and $50 \mathrm{~m}$ long. The qualities of the topographic bases used for the three basins were as follows: $1 \mathrm{~m}$ cell resolution for the Rudan and Chiesa catchments and $0.5 \mathrm{~m}$ cell resolution for the Rebaixader catchment. In Tab. 2, the width and bed slope (both in $\mathrm{m} / \mathrm{m}$ and in degrees) of the cross-sections are reported for a depth $(y)$ of $1 \mathrm{~m}$; this table also shows the mean grain size of the active triggering zone measured using the pebble-count method sampled by line (approximately 100 data samples).

Then, for every cross-section, we calculated the critical discharge per unit width $\left(q_{c}, \mathrm{~m}^{2} / \mathrm{s}\right)$ related to the initiation of a debris flow surge (Fig. 5) using two different equations:

1. The first one is the equation proposed by [19], that is as follows: 
Table 2: Main parameters of the control cross-sections: $d_{m}$ is the mean grain-size diameter of the considered triggering area, $S$ is the mean hillslope gradient expressed in $\mathrm{m} / \mathrm{m}, \beta$ is the hillslope gradient expressed in degrees, $B$ is the section width and $y$ is the related hydraulic depth.

\begin{tabular}{|c|c|c|c|c|c|c|c|c|c|}
\hline & \multicolumn{3}{|c|}{$\begin{array}{c}\text { Rudan } \\
d_{m}=0.15 \mathrm{~m}\end{array}$} & \multicolumn{3}{|c|}{$\begin{array}{c}\text { Chiesa } \\
d_{m}=0.10 \mathrm{~m}\end{array}$} & \multicolumn{3}{|c|}{$\begin{array}{l}\text { Rebaixader } \\
d_{m}=0.10 \mathrm{~m}\end{array}$} \\
\hline & Sec 1 & $\operatorname{Sec} 2$ & $\operatorname{Sec} 3$ & $\operatorname{Sec} 1$ & $\operatorname{Sec} 2$ & $\operatorname{Sec} 3$ & Sec 1 & $\operatorname{Sec} 2$ & $\operatorname{Sec} 3$ \\
\hline$S(\mathrm{~m} / \mathrm{m})$ & 0.61 & 0.67 & 0.49 & 0.81 & 0.68 & 0.70 & 0.33 & 0.47 & 0.43 \\
\hline$\beta\left({ }^{\circ}\right)$ & 31.38 & 33.82 & 26.10 & 39.01 & 34.22 & 34.99 & 18.33 & 25.14 & 23.11 \\
\hline$B$ at $y=1 \mathrm{~m}$ & 3.51 & 6.18 & 11.5 & 9.10 & 9.31 & 5.44 & 7.56 & 11.61 & 5.51 \\
\hline
\end{tabular}

$$
q_{c}=0.78 \frac{d_{m}^{1.5}}{\tan \beta^{1.27}}
$$

Where $d_{m}$ is the mean grain size (via the pebble-count method) of the terrain in the triggering zone (channel bed), and $\beta$ is the mean hillslope gradient in the corresponding cross-section. For the Rudan and Chiesa catchments, the mean diameters $\left(d_{m}\right)$ were measured during the surveys conducted for the construction of the two filter check-dams in the basins [41, 42]; whereas, for the Rebaixader catchment, the mean diameter was measured during a field survey in summer 2018.

2. The second equation used to calculate the critical discharge of every crosssection is the one proposed by [47]. This equation was developed to calculate the critical discharge capable of mobilizing sediments (mainly composed of granular material), causing the destabilization of artificial blockramps (consolidation work built with boulders):

$$
q_{c}=0.257(s-1)^{0.5} g^{0.5} d_{m}^{1.5} \tan \beta^{-1.17}
$$


Where, $s$ is the ratio of the sediment density to the density of water, and $g$ is the gravitational acceleration. In this formula, the calculation refers to the erosion of block-ramps with large blocks. Hence, we tested two different grain sizes $\left(d_{\mathrm{m}}=0.3 \mathrm{~m}\right.$ and $\left.d_{\mathrm{m}}=0.5 \mathrm{~m}\right)$ to give the corresponding discharge range for the destabilization of the sparse boulders present on the channel bed and banks inside the source area material.

After that, to calculate the critical water discharge $Q\left(\mathrm{~m}^{3} / \mathrm{s}\right)$ of every section, corresponding to the discharge per unit width calculated with Eqs. 1 and 2, we used a MATLAB computational code (MATLAB analysis in Fig. 5). This tool allows to analyze a cross section using as input: the Manning's roughness $(n)$ and the $x y$ coordinates of the section expressed in meters. The result is a table in which, for increasing values of flow height $y(\mathrm{~m})$ - from the bottom to the top of the section - the following parameters are shown: wet area $A\left(\mathrm{~m}^{2}\right)$, width $B$ (m), wet perimeter $C(\mathrm{~m})$, hydraulic radius $R_{h}(\mathrm{~m})$, flow velocity $v(\mathrm{~m} / \mathrm{s})$, flow discharge $Q\left(\mathrm{~m}^{3} / \mathrm{s}\right)$, mean bed shear stress $\tau\left(\mathrm{N} / \mathrm{m}^{2}\right)$ and discharge per unit width $q\left(\mathrm{~m}^{2} / \mathrm{s}\right)$.

The stage-mean flow velocity relationship used by the MATLAB code to calculate water discharge $\left(Q, \mathrm{~m}^{3} / \mathrm{s}\right)$ is the turbulent uniform flow equation:

$$
Q=A \frac{1}{n}(\sin \beta)^{0.5} R_{h}^{\frac{2}{3}}
$$

where $n$ is the Manning's roughness coefficient of the analyzed section. Based on literature findings for very low relative submergences $\left(R_{h}\right.$ divided by a reference coarse grain size) $[49,50]$ we assumed a Manning's $n$ value of 0.1 .

Whereas, the mean bed shear stress $\tau\left(\mathrm{N} / \mathrm{m}^{2}\right)$ is calculated using the Du Boys equation: 


$$
\tau=\gamma_{\mathrm{w}} R_{h} \tan \beta
$$

where $\gamma_{w}$ is the specific weight of water (this is physically consistent because we are considering the water runoff for the initiation of a debris flow and not a mature debris flow wave).

For every cross section, in the resulting table from the MATLAB tool, we searched for the $q\left(\mathrm{~m}^{2} / \mathrm{s}\right)$ values previously calculated with Eq.s 1 and 2 and we extracted the corresponding $Q\left(\mathrm{~m}^{3} / \mathrm{s}\right)$ values (CRITICAL DISCHARGE step in Fig. 5).

The application of Eqs. 1-2 has been done in the three cross sections to have a global view of the headwater basin behavior. It is worth noting that Eq.s 1 and 2 are meaningful if they refer to a well confined flow at low flow stages. Therefore, the critical threshold values obtained at Section 3 (hydrological modelling outlet, see Section 3 in Figs. 6-7-8) are considered the most reliable, with a well confined flow occurring here in all three basins.

To create the hyetographs to be used as input in the hydrological simulations, we accounted for some empirical intensity-duration equations found in the literature. In particular, we chose between three intensity-duration equations already used in other investigations: [29], [31] and [35]. To choose the equations that are close to the typical rainfall events of each basin, we analyzed real rainfall events associated with triggered debris flows.

The selection of the appropriate equation was carried out specifically for each basin:

For the Rudan catchment, we simply calibrated the equation suggested by [35]: 


$$
I_{M}=21.0 D^{-0.55}
$$

where $I_{M}$ is the mean hourly intensity, and $D$ is the duration. We chose this equation because [35] already used it in the determination of critical rainfall events for a dolomitic zone that includes our catchment.

For the Chiesa catchment, we selected five rainfall events that, over the last 20 years, have triggered torrential flows: 20/09/2000, 28/07/2003, 26/07/2006, $8 / 08 / 2015$ and $04 / 07 / 2018$. The rainfall data of the first four events were registered by the rain gauge of "Passo Falzarego", located about $4 \mathrm{~km}$ from the catchment, and the rainfall data of the last event (04/07/2018) was registered by a new rain gauge installed during 2017 inside the catchment area. For every rainfall event, we extracted the strongest rainfall burst, characterized by a minimum precipitation of $1 \mathrm{~mm}$ in 5 minutes. For every burst, we calculated the corresponding medium hourly intensity for different durations: 5, 10, 20, 30 and 60 minutes. We reported these values in a graph with the three intensity-duration equations from the literature (Fig. 9). The graph shows that the majority of the real bursts points are located near the equation of [29]:

$$
I_{M}=30.7 D^{-0.45}
$$

For this reason, we chose this equation to create the hyetographs for the hydrological simulations.

For the Rebaixader catchment, we conducted a similar analysis using four triggering rainfall events: 11/07/2010, 27/06/2012, 4/07/2012 and 31/07/2015. The rainfall data of these events were registered by a raing gauge installed inside the catchment area [44]. We extracted the bursts of these events and compared 
the points with the empirical equations (Fig. 9). In addition, for this case, we selected the equation of [29] as two events lie below and two events lie above this curve. Therefore, it seems this equation can, on average, better represent typical triggering rainfall events.

To create the input hyetographs for the hydrological simulations, we used four total rainfall durations: 15, 30, 60 and 120 minutes. Using Eqs. 5 and 6, we calculated the corresponding intensity for each rainfall duration (these were the analyzed intensities linked to the critical duration, which generated the exact debrisflow-triggering discharge at Section 3). Finally, using these intensity values, we created eight different input hyetographs with constant duration (see the example in grey at the right bottom of Fig. 5).

The rainfall-runoff simulations were conducted by means of the FLO-2D model [5]. FLO-2D is a bidimensional numerical model used to perform hydrologichydraulic simulations. Certified by FEMA (Federal Emergency Management, USA), FLO-2D is widely used to analyze the effects of floods on alluvial areas, fans, rivers and mountain torrents. The model works by means of the DTM maps of the analyzed basins. For each cell, the runoff propagation is calculated on the quadratic matrix composed by itself and the neighboring cells, which is possible in all eight directions. Two equations are used for the calculation of flow: the dynamic equation (Sant Vénant) and the equation of mass conservation. The main parameters that influence the results are: (1) the grid dimensions of the DTM cells used to create the floodplain, (2) the altitude, $n$-Manning (variable values from cell to cell) and mean catchment value of $C N$ (curve number, [51]), and (3) the input hyetographs [5]. We used this model because it allows different types of hydrological simulations to be conducted using specific input parameters such as 
Table 3: Percentages of the superficial extent of different land uses in the three headwater basins and the calculated mean $\mathrm{CN}$ values.

\begin{tabular}{cc|cc|cc}
\hline \multicolumn{2}{c|}{} & \multicolumn{2}{c|}{ Chiesa } & \multicolumn{2}{c}{ Rebaixader } \\
Land type & Area (\%) & Land type & Area (\%) & Land type & Area (\%) \\
\hline Shrubs & 4 & Woods & 32 & Woods & 75 \\
Pastures & 10 & Pastures & 56 & Pastures & 16 \\
Scree & 10 & Scree & 3 & Scree & 9 \\
Rocks & 76 & Rocks & 9 & & \\
\hline \multicolumn{2}{c|}{ Mean CN $=78$} & Mean CN $=75$ & \multicolumn{2}{c}{ Mean CN = 65 } \\
\hline
\end{tabular}

the rainfall hyetograph and the detailed characteristics of the area at the spatial resolution of the DTM grid, enabling the immediate, simultaneous extraction of predicted runoff in different selected cross-sections. For the hydrological simulations, we used a mean unique $\mathrm{CN}$ for each basin, rather than a distributed $\mathrm{CN}$, as the total size of the three catchments is low, and after verifying that the distributed $\mathrm{CN}$ assignment does not significantly change the results, particularly for strong rainfall events. Tab. 3 shows the different hydrological modelling areas and the corresponding mean $\mathrm{CN}$ values. The values agree with the $\mathrm{CN}$ assignments in comparable small mountain catchments where rainfall-runoff data were available for calibration [11].

Regarding the initial abstraction (infiltration and interception water losses at the beginning of the precipitation events), we used a value of $1 \mathrm{~mm}$ in all the simulations. Many authors have suggested that lower initial abstraction values give better simulation results than higher abstraction values in the case of steep slope catchments $[19,52,53,11]$.

We conducted the hydrological simulations, modelling the flood hydrographs 
originating from the input hyetographs. We analyzed the resulting peak discharge in each of the three control cross-sections (Figs. 6-7-8) to verify if the peak discharge exceeded the critical discharge, which was previously calculated from Eqs. 1 and 2. Finally, we performed additional simulations, varying the rainfall event duration until we found the exact rainfall duration corresponding to the critical discharge for the mobilization of sediments in the studied channels.

The hydrological calibration of the simulations was not possible using real flood hydrograph observations due to the low accessibility of the triggering areas and overall difficulty of gauging the flow rates in small, steep and unstable channels. Therefore, to verify the influence of the mean $\mathrm{CN}$ value on the results, we performed additional simulations by varying the assignment of the mean $C N$ value, which was quoted approximatively for about $10 \%$ according to the findings of [54]. The repeated simulations were then analysed to indicate the extent to which our conclusions might be biased by the lack of a rainfall-runoff calibration.

\subsection{Slope stability approach}

To complete the analysis, we studied the slope stability of the triggering areas using the geotechnical data of the soil. This second analysis allowed us to also consider the second triggering mechanism, which is the mechanism related to the potential hillslope instability, which can evolve into a shallow slope failure and consequently into a debris flow.

Therefore, to consider the possibility that a debris flow will be triggered due to a concurrent shallow landslide, we performed a stability analysis of the triggering areas. The objective of this part focused on determining at which position of the water table the hillslope nearby the triggering area becomes unstable or prone to collapse [22]. To carry out this analysis, we first collected some samples of the soil 
matrix in the triggering areas. Then, the geotechnical analyses were performed by professional laboratories to extract the soil characteristics (Tab. 4).

Using these characteristics, we conducted the infinite slope analysis of the three triggering areas, calculating the stability factor $(F S)$ with the equation proposed by [55]:

$$
F S=\frac{c^{\prime}+\left(\gamma_{s}-m \gamma_{w}\right) z \cos \beta^{2} \tan \phi}{\gamma_{s} z \cos \beta \sin \beta}
$$

Where (see Tab. 4) $c^{\prime}$ is the effective cohesion, $z$ is the height of the potential sliding plane, $m$ is the water table parameter (the fraction of the $z$ depth where the water table is located), $\beta$ is the hillslope gradient, $\gamma_{s}$ is the saturated soil unit weight and $\gamma_{w}$ is the water unit weight $\left(9.81 \mathrm{kN} / \mathrm{m}^{3}\right)$. According to literature findings $[56,57]$ the debris flow occurs below the condition of full saturation of the bed and then the reliable $m$ range has been taken not higher than 0.8 . To assess $\beta$, we extracted the hillslope gradient of the zones right above the channel initiation points in the three source areas, measuring this gradient in a $50 \mathrm{~m}$ long segment. Therefore, these values are the average slopes of the triggering areas, and the real values might increase locally.

If the safety factor $(F S)$ is greater than 1.0, the hillslope is stable, whereas, when $F S$ approaches or is lower than 1.0, the hillslope becomes unstable, and the possibility of a shallow landslide exists.

\section{Results}

\subsection{Results of the hydrological analysis}

Regarding the results of the critical discharge analysis, Tab. 5 shows that the critical discharges per unit width obtained using the equation of [19] are generally 
Table 4: Main geotechnical parameters resulting from the laboratory analysis of the soil matrix samples collected inside the three hydrological modelling areas.

\begin{tabular}{lccc}
\hline & Rio Rudan* & Rio Chiesa* & Rio Rebaixader** \\
\hline Saturated soil unit weight $\left(\gamma_{s}\right)\left(\mathrm{kN} / \mathrm{m}^{3}\right)$ & 17.52 & 17.98 & 17.70 \\
Soil friction angle $\left(\varphi^{\prime}\right)\left({ }^{\circ}\right)$ & 42.50 & 36.50 & 40.00 \\
Effective Cohesion $\left(c^{\prime}\right)(\mathrm{kPa})$ & 10.00 & 12.00 & 4.00 \\
Mean hillslope gradient $(\beta)\left(^{\circ}\right)$ & 31 & 40 & 31 \\
\hline
\end{tabular}

* GEODATA Laboratory (Ponte San Nicolò, Padova, Italy)

** Geomar and UPC Laboratory (Barcelona, Spain)

low (between 0.03 and $0.12 \mathrm{~m}^{2} / \mathrm{s}$, Tab. 5). It is interesting that the value of $\tau_{\mathrm{c}}$ for the Chiesa and Rebaixader catchments are very similar in terms of shear stress, whereas in the Rudan basin, these values are slightly higher (Tab. 5). Looking at Tab. 5 it can be noticed that we found a very narrow range of triggering discharges and shear stresses, which varies from 0.04 to $0.20 \mathrm{~m}^{3} / \mathrm{s}$ and from 272 to $413 \mathrm{~N} / \mathrm{m}^{2}$, respectively.

To verify the influence of the slope extraction on the resulting discharges we conducted a sensibility analysis in the three cross-sections at the basin outlets, using different reach lenghts $(10,30$ and $50 \mathrm{~m})$ to extract the terrain slope. It has been verified that the unit critical discharge values only vary within a small range of -0.02 to $+0.01 \mathrm{~m}^{2} / \mathrm{s}$, meaning that the different reach lengths used for the slope extraction had a minimum influence on the calculated discharges.

Using the equation for block-ramps proposed by [47] with two different diameters (Tab. 6), the critical discharge is obviously higher because the runoff needed 
for the mobilization of larger blocks is greater.

Table 5: Critical hydraulic parameters derived from [19] (Eq. 1) of the analyzed cross-sections.

Values bold-italic are for the cross-sections at the hydrological modelling area outlet.

\begin{tabular}{l|ccc|cccc|ccc}
\hline & \multicolumn{3}{|c|}{ Rudan } & \multicolumn{3}{c|}{ Chiesa } & \multicolumn{3}{c}{ Rebaixader } \\
& Sec 1 & Sec 2 & Sec 3 & Sec 1 & Sec 2 & Sec 3 & Sec 1 & Sec 2 & Sec 3 \\
\hline $\mathrm{q}_{c}\left(\mathrm{~m}^{2} / \mathrm{s}\right)$ & 0.12 & 0.08 & $\mathbf{0 . 0 9}$ & 0.03 & 0.04 & $\mathbf{0 . 0 4}$ & 0.10 & 0.06 & $\boldsymbol{0 . 0 7}$ \\
$\mathrm{Q}_{\mathrm{c}}\left(\mathrm{m}^{3} / \mathrm{s}\right)$ & 0.19 & 0.13 & $\mathbf{0 . 1 6}$ & 0.02 & 0.04 & $\mathbf{0 . 0 3}$ & 0.20 & 0.10 & $\boldsymbol{0 . 0 8}$ \\
$\tau_{\mathrm{c}}\left(\mathrm{N} / \mathrm{m}^{2}\right)$ & 353 & 358 & $\mathbf{4 1 3}$ & 272 & 263 & $\mathbf{2 6 7}$ & 282 & 288 & $\mathbf{2 9 0}$ \\
\hline
\end{tabular}

The results (Tab. 7) demonstrate that the critical rainfall duration needed to reach the critical discharge for debris flow initiation (equation 1 of [19]) ranges between 12 and 22 minutes in the three basins. Moreover, the Rudan catchment shows the lowest rainfall intensity, while Chiesa catchment shows the highest and consequently is characterized by the minimum rainfall duration required to reach the critical value for the initiation of sediment mobilization (Tab. 6).

In Fig. 10, the hydrographs corresponding to Section 3 of the three catchments, located at the hydrological modelling area outlet, are shown. Among the three basins, the Rudan catchment is characterized by the highest critical discharge.

In the Rebaixader simulation area, the critical discharge corresponding to the possible triggering of debris flows is between the values of the two other basins (Tab. 5). Nevertheless, in this case, the rainfall duration needed to reach the critical discharge at the headwater basin outlet is very similar to that of Rudan headwater basin (Tab. 7) and the hydrograph resulting from the 15-minute rainfall duration is lower than the threshold (Fig. 10). 
Table 6: Critical hydraulic parameters derived from [47] (Eq. 2, used for the erosion of blockramps) of the analysed cross-sections, using the two diameters of $0.3 \mathrm{~m}$ (value before the slash) and of $0.5 \mathrm{~m}$ (value after the slash). Values in bold-italic are for the cross-sections at the hydrological modelling area outlets.

\begin{tabular}{l|ccc|ccc|ccc}
\hline & \multicolumn{3}{|c|}{ Rudan } & \multicolumn{3}{c|}{ Chiesa } & \multicolumn{3}{c}{ Rebaixader } \\
& Sec 1 & Sec 2 & Sec 3 & Sec 1 & Sec 2 & Sec 3 & Sec 1 & Sec 2 & Sec 3 \\
\hline $\mathrm{q}_{\mathrm{c}}$ & $0.27 /$ & $0.19 /$ & $\mathbf{0 . 2 1 /}$ & $0.15 /$ & $0.19 /$ & $\mathbf{0 . 1 8 /}$ & $0.41 /$ & $0.27 /$ & $\mathbf{0 . 3 0 /}$ \\
$\left(\mathrm{m}^{2} / \mathrm{s}\right)$ & 0.58 & 0.40 & $\mathbf{0 . 4 5}$ & 0.33 & 0.41 & $\mathbf{0 . 3 9}$ & 0.89 & 0.60 & $\mathbf{0 . 6 5}$ \\
\hline $\mathrm{Q}_{\mathrm{c}}$ & $0.47 /$ & $0.25 /$ & $\mathbf{0 . 4 3 /}$ & $0.22 /$ & $0.58 /$ & $\mathbf{0 . 2 9 /}$ & $1.59 /$ & $0.87 /$ & $\mathbf{1 . 2 6 /}$ \\
$\left(\mathrm{m}^{3} / \mathrm{s}\right)$ & 1.74 & 1.34 & $\mathbf{1 . 0 3}$ & 0.85 & 2.62 & $\mathbf{0 . 8 9}$ & 4.08 & 2.32 & $\mathbf{3 . 3 5}$ \\
\hline$\tau_{\mathrm{c}}$ & $528 /$ & $455 /$ & $\mathbf{6 6 2 /}$ & $660 /$ & $702 /$ & $\mathbf{6 6 7 /}$ & $654 /$ & $670 /$ & $\mathbf{6 6 3 /}$ \\
$\left(\mathrm{N} / \mathrm{m}^{2}\right)$ & 925 & 945 & $\mathbf{1 0 5 0}$ & 1073 & 1089 & $\mathbf{1 0 7 1}$ & 1022 & 1048 & $\mathbf{1 0 4 0}$ \\
\hline
\end{tabular}

Considering the critical runoff discharge (Tab. 6) and shear stress values obtained using Eq. 2 proposed by [47], we demonstrated a range of values triggering more powerful and destructive debris flows, characterized by the overall collapse of the torrent bed (involving blocks of great dimensions). In this case, the values required to reach these critical discharges are high and range for the outlet section between 0.29 and $1.26 \mathrm{~m}^{3} / \mathrm{s}$ for $\mathrm{d}_{\mathrm{m}}=0.3 \mathrm{~m}$; in addition, hydrological simulations show that the rainfall duration needed for the mobilization of boulders in the source area is between 30 and 60 minutes.

\subsection{Results of the slope stability analysis}

The slope stability analysis indicates that the Rudan and Rebaixader catchments remain generally stable for important depths of the potential sliding plane (Fig. 11). These basins show a hillslope terrain of approximately $31^{\circ}$ and soil 
Table 7: Main parameters of the hyetographs used for the FLO-2D hydrological simulations in the three basins and the corresponding peak discharges resulting from the simulations in the outlet cross-section ( $\mathrm{D}_{\text {tot }}$ is the total duration, and $\mathrm{P}_{\text {tot }}$ is the total precipitation). In the last line, bolditalic values were obtained with the FLO-2D simulation, in which the resulting $\mathrm{Q}_{\max }$ approaches the best the $\mathrm{Q}_{\mathrm{c}}$ calculated with Eqs. 1 and 2.

\begin{tabular}{|c|c|c|c|c|c|c|c|c|c|c|c|}
\hline \multicolumn{4}{|c|}{ Rudan } & \multicolumn{4}{|c|}{ Chiesa } & \multicolumn{4}{|c|}{ Rebaixader } \\
\hline $\begin{array}{r}\mathrm{D}_{\text {tot }} \\
(\mathrm{min}\end{array}$ & $\begin{array}{c}\mathrm{P}_{\text {tot }} \\
(\mathrm{mm})\end{array}$ & $\begin{array}{c}\mathrm{I} \\
(\mathrm{mm} / \mathrm{h})\end{array}$ & $\begin{array}{l}\mathrm{Q}_{\max } \\
\left(\mathrm{m}^{3} / \mathrm{s}\right)\end{array}$ & $\begin{array}{l}D_{\text {tot }} \\
(\min \end{array}$ & $\begin{array}{c}\mathrm{P}_{\text {tot }} \\
(\mathrm{mm})\end{array}$ & $\begin{array}{c}\mathrm{I} \\
(\mathrm{mm} / \mathrm{h})\end{array}$ & $\begin{array}{l}\mathrm{Q}_{\max } \\
\left(\mathrm{m}^{3} / \mathrm{s}\right)\end{array}$ & & $\begin{array}{c}\mathrm{P}_{\mathrm{tot}} \\
(\mathrm{mm})\end{array}$ & $\begin{array}{c}\mathrm{I} \\
(\mathrm{mm} / \mathrm{h}\end{array}$ & $\begin{array}{l}\mathrm{Q}_{\max } \\
\left(\mathrm{m}^{3} / \mathrm{s}\right)\end{array}$ \\
\hline 15 & 11.25 & 45.00 & 0.02 & 15 & 14.32 & 57.28 & 0.08 & 15 & 14.32 & 57.28 & 0.02 \\
\hline 30 & 15.37 & 30.74 & 0.36 & 30 & 20.97 & 41.94 & 0.46 & 30 & 20.97 & 41.94 & 0.14 \\
\hline 60 & 21.00 & 21.00 & 0.98 & 60 & 30.70 & 30.70 & 1.14 & 60 & 30.70 & 30.70 & 0.88 \\
\hline 120 & 28.68 & 14.34 & 1.37 & 120 & 44.95 & 22.47 & 1.43 & 120 & 44.95 & 22.47 & 1.37 \\
\hline 22 & 13.36 & 36.43 & 0.13 & 12 & 12.61 & 63.05 & 0.04 & 22 & 17.68 & 48.21 & 0.07 \\
\hline
\end{tabular}

friction angle higher than $40^{\circ}$ (Tab. 4); thus, the slope of the triggering areas are lower than the friction angle. In contrast, in the case of the Chiesa basin, the hillslope slope is approximately $40^{\circ}$, and the soil friction angle is $36.5^{\circ}$ (Tab. 4). For this reason, as observed in Fig. 11, when the thickness of slipping approaches 2.5 meters (shallow landsliding), the hillslope becomes unstable, and the stability factor reaches the stability threshold, particularly for $m$ values of approximately 0.8 .

\section{Discussion}

For the first and second triggering mechanisms (i.e. bed failure due to progressive bed erosion and bed failure due to full bed breakge), considering the range of critical discharges resulting from Eq. 1 and Eq. 2, we can assume that this in- 
terval includes the maximum probability for debris flow triggering. Our analysis indicates that the critical discharge for the initiation of debris flow, as calculated with Eq. 1, is generally low even accounting for different triggering locations and geomorphological characteristics. Moreover, this discharge can be generated by short and intense rainfall events with a duration between approximately 10 and 20 minutes if the rainfall intensity follows the threshold curves. The highest value of critical discharge in the three study areas resulted in the Rudan catchment. This higher value is likely derived from the larger channel width and coarser mean diameter of the Rudan catchment than of the other areas and this is due to the different geological characteristics of the study areas.

The maximum flow rates that we hydrologically identified with this approach are comparable with the values measured in some dolomitic headwater basins by [11]. The associated threshold intensities, which are provided by Eq.s 4-5 type curves, are undoubtedly a fundamental variable but a lower limit of their duration resulted necessary to generate debris flows. This confirms that excess infiltration overland flow plays a key role as it is supported by the agreement between the hydrological $\mathrm{CN}$-based simulations and the observed times of debris flow triggering (Fig. 9).

Our results would not change significantly if all hydrological simulations were repeated by considering the $\mathrm{CN}$ variation within an acceptable range of $\pm 10 \%$. For example, under this hypothesis, the critical duration needed to reach critical discharge in section 3 of the Rebaixader catchment would vary in the interval of 18-30 minutes. In short, accounting for the acknowledgement on the $\mathrm{CN}$ hydrological modelling, the selection of a $\mathrm{CN}$ value inside $\mathrm{a} \pm 10 \%$ interval is not a real limitation, being the simulated flow-rates in an acceptable range of uncertaintes. 
Conversely, if the channel banks are characterized by the presence of blocks with dimensions greater than $0.3 \mathrm{~m}$ at least partially armoring the bed bottom or buried near to the bed surface (critical discharge of [47] calculated with Eq. 2), a longer rainfall duration is needed for the mobilization of sediments, postponing the triggering of high-intensity debris flow.

The outlet cross-section in each considered catchment does not show the highest critical discharge of the three selected sections. In the Rudan basin, the highest critical discharge corresponds to cross-section 1, which is the section located in the left channel inside the upper part of the source area. In the Chiesa basin, the maximum critical discharge corresponds to cross-section 2, which is positioned in the central part of the channel crossing the source area. Finally, in the Rebaixader basin, the highest critical discharge corresponds to cross-section 1, which again is located in the highest part of the source area. Therefore, it seems that generally, along the uppermost erosive paths inside the source areas, the critical runoff needed for the mobilization of sediments is higher than that at the outlet section, which is the weakest in terms of stability. This means that the rainfall intensities and durations needed to destabilize these zones of the source areas are slightly higher than those observed at the outlets of the hydrological modelling areas and this behavior seems independent from the morphological and geological settings of the basin. In conclusion, the zones more prone to a mobilization result to be located at the toe of the source area as consequence of a combination of upslope area (that is the rate of overland and/or channel flow) and local slope.

The maximum probability in terms of the necessary flow rate for debris-flow initiation could be determined by selecting, for every triggering area, the maximum hazard values of different control cross-sections in which the process might 
take place.

Moreover, the critical runoff discharge found in our study for the mobilization of sediments is comparable to the discharge found by [58], who reported a value of $0.15 \mathrm{~m}^{3} / \mathrm{s}$ for the in-channel runoff needed to start a debris flow; they also stated that a high antecedent moisture level in the soil is not required for the debris flow initiation. The behavior of the Rudan headwater basin can be compared to that of the Chalk Cliffs catchment [58]; apparently, in this type of basin characterized by sedimentary rocks and wide source areas surronded by steep rock faces, debris flows initiate because intense rainfall events fall on the rocky faces and couloirs, generating critical runoff that abruptly mobilizes sediments located in the underlying talus cones. This typical triggering behavior has been already described by various authors in recent years $[18,19,59,11]$, and our simulated hydrological behavior highlights the strong capacity of water to initiate the massive mobilization of sediments on steep slopes. To protect populations living downstream of these critical zones, it is important to understand this behavior: the high amount of material stored in source areas, the generally low runoff discharge needed for the mobilization of sediments and the frequency of intense and short thunderstorms during summer $[18,40,43,60]$ make these areas strongly susceptible to debris flows. From the perspective of population protection and based on our findings, we suggest that the drainage and diversion of small discharges in the triggering zones could provide great benefits in the reduction of debris flows in terms of magnitude and frequency of occurrence.

The critical shear stresses resulting from the control cross-section analyses are comparable among the three basins, meaning that similar erosive shear forces are needed to mobilize the sediments inside the channels. Nevertheless, the Chiesa 
and Rebaixader catchments, characterized by wide steep eroded hillslopes, show slightly smaller critical shear stresses than the Rudan basin. The Rudan basin is characterized by a steep talus cone rich in large boulders surrounded by rock faces, and it seems that this morphology compared to the Chiesa and Rebaixader morphologies requires increased stress to mobilize sediments in the channel bed.

The Rudan and Rebaixader catchments in particular are characterized by the presence of big blocks in the triggering areas [61]. Therefore, the second discharge initiation threshold derived with the formula of [47] assumes an important relevance in the comprehension of both a second level of triggering mechanism (i.e. full bed breakage) and the following overall dynamics after the first surge formation. The mobilization of these big blocks is the consequence of a high water discharge that could result in the generation of debris flows near the maximal values in terms of both flow peaks and total sediment volumes. Exceeding this second flow rate threshold could confirm that the link between the amount of debris flow-triggering precipitation and the debris flow volume is discontinuous when linked with the macroscopic bimodal nature of grain size distribution of the debris flow material (e.g., boulders and coarse cobbles immersed in a fine matrix). Consequently, when full-bed breakage occurs, the debris flow volume suddenly increases and/or a debris flood becomes debris flow [36].

Regarding the slope stability analysis [55], the water table is difficult to define in the field, particularly in cases when no clear water table is distinguishable (e.g., the Rebaixader catchment). In these cases, the approaches using unsaturated soil mechanics may yield more realistic results, but the uncertainty of such methods is high because they require more geotechnical parameters (e.g. soil retention curve, or Van Genuchten parameters) that are very difficult to assess with precision at 
high steepness and locally variable conditions. Therefore, even if the suction may play a certain role, we applied the infinite slope method in presence of water table because the goal was an overall indication on the potential sliding of the source area and the cross comparison with the other two mechanism of debris flow occurrence.

Analysing Fig. 11 and considering a reference soil thicknesses for instability (i.e. $z=2.0 \mathrm{~m}$ ), the Chiesa catchment appears the nearest to the mechanism of shallow slope failure [2], closely followed by the Rebaixader. When the $m$ water table parameter exceeeds 0.5 (Fig. 11b, c) the hillslope condition becomes really close to the instability. Both basins differ from the Rudan basin being both characterized by a poorly confined and lowly channelized source area. Chiesa and Rebaixader basins seem generate debris flows dependent both on the partial soil saturation and runoff concentration. On the contrary, the Rudan catchment - the only source area bounded at the head by rocky cliffs incised by hydrologically converging faults - shows a higher hillslope stability (greater $F S$ in Fig. 11a) confirming that in a Dolomitic context (comparable with that of the Rudan) the pure channel bed erosion and failure prevails. This might happen during rainfall events because intensive bed erosion and full bed breackage anticipate the full conditions of slope failure that in turn would require longer time. Thus at the triggering, the channel bed and the surrounding hillslopes are quite far from soil saturation ([57]; e.g . Fig. 11a, with $m=0.5$ ) and the flow rate stressing the source area and exceeding the threshold values represents the driving conditions for debris flow initiation. The two different behaviours could be classified as 'flow rate dominant' in the Rudan-type basins and 'mixed (flow rate/slope stability)' in the Chiesa-Rebaixader type basins. 


\section{Conclusions}

Considering the results obtained from this study, we can state that:

- Even if many intensity-duration curves are computed to determine the triggering of debris flows, it seems that an additional minimum duration threshold is needed, so that below this limit, the initiation of a debris flow is very unlike to occur.

- The critical rainfall duration associated with a high triggering probability ranges between 12 and 22 minutes in the three study areas (basin areas between 0.48 and $0.82 \mathrm{~km}^{2}$ ).

- The critical discharge needed to initiate a debris flow surge is generally low (between 0.03 and $0.28 \mathrm{~m}^{3} / \mathrm{s}$ ), meaning that a relatively low water runoff at the outlet of the source area is needed to mobilize sediments inside the channel and triggers debris flow phenomena.

- The critical discharge range derived from the two equations [47, 19] highlights the interval in which the debris flow triggering probability is higher. In particular, in all the basins, a 60 minute rainfall with critical intensity is capable of generating a water peak discharge exceeding the threshold for the mobilization of boulders larger than $0.3 \mathrm{~m}$ (dam-break scenario). This means that real rainfall events with similar characteristics can possibly trigger torrential events where the magnitude order of debris flow volumes suddenly switches. This behaviour seems more probable in those catchments whose source area is composed by abundant fine matrix coexisting with an appreciable amount of boulders and large cobbles. 
- The central parts of the source areas represent the zones that need the highest water discharge to be destabilized. This indicates that these reaches of the gullies require a higher rainfall duration than other areas to initiate a debris flow surge and that source area instability migrate from downstream to upstream during an over-threshold rainfall event.

- The different catchment morphologies influence the main triggering mechanism in addition to the 'basic' progressive bed erosion; therefore, in Rudanlike basins, channel bed failure seems to be the dominant mechanism, whereas in basins similar to Rebaixader and Chiesa, the shallow slope failure mechanism or a mix between the two types of mechanisms is more likely to occur.

\section{Acknowledgments}

Research at Rebaixader is funded by the Ministry of Economy and Competitiveness of Spain (SMuCPhy project, BIA 2015-67500-R). Fondazione Ing. Aldo Gini funded Roberta Pastorello with a scholarship to spend 6 months at BarcelonaTECH (UPC) during 2016.

\section{References}

[1] O. Hungr, S. Leroueil, L. Picarelli, The Varnes classification of landslide types, an update, Landslides 11 (2) (2013) 167-194. doi:10.1007/s10346013-0436-y.

[2] D. Rickenmann, Methods for the quantitative assessment of channel processes in torrents (steep streams), CRC Press, Taylor and Francis Group, Leiden, Netherlands, 2016. 
[3] G. H. Eisbacher, Slope stability and Land Use in Mountain Valleys, Geoscience Canada 9 (1) (1982) 14-27.

[4] S. Fuchs, R. Kaitna, C. Scheidl, J. Hübl, The Application of the Risk Concept to Debris Flow Hazards, Geomechanik und Tunnelbau 1 (2) (2008) 120-129. doi:10.1002/geot.200800013.

[5] J. O'Brien, P. Julien, W. Fullerton, Two-Dimensional water flood and mudflow simulation, Journal of Hydraulic Engineering 119 (2) (1993) 24-261. doi:10.1061/(ASCE)0733-9429(1993)119:2(244).

[6] A. Burton, J. C. Bathurst, Physically based modelling of shallow landslide sediment yield at a catchment scale, Environmental Geology 35 (2-3) (1998) 89-99. doi:10.1007/s002540050296.

[7] G. B. Crosta, P. Frattini, Distributed modelling of shallow landslides triggered by intense rainfall, Natural Hazards and Earth System Sciences 3 (1/2) (2003) 81-93.

[8] A. Armanini, L. Fraccarollo, G. Rosatti, Two-dimensional simulation of debris flows in erodible channels, Computers and Geosciences 35 (5) (2009) 993-1006. doi:10.1016/j.cageo.2007.11.008.

[9] O. Hungr, S. McDougall, Two numerical models for landslide dynamic analysis, Computers and Geosciences 35 (5) (2009) 978-992. doi:10.1016/j.cageo.2007.12.003.

[10] P. Horton, M. Jaboyedoff, B. Rudaz, M. Zimmermann, Flow-R, a model for susceptibility mapping of debris flows and other gravitational hazards at 
a regional scale, Natural Hazards and Earth System Science 13 (4) (2013) 869-885. doi:10.5194/nhess-13-869-2013.

[11] C. Gregoretti, M. Degetto, M. Bernard, G. Crucil, A. Pimazzoni, G. De Vido, M. Berti, A. Simoni, S. Lanzoni, Runoff of small rocky headwater catchments: Field observations and hydrological modeling, Water Resources Research 52 (10) (2016) 8138-8158. doi:10.1002/2016WR018675.

[12] T. Takahashi, Estimation of potential debris flows and their hazardous zones; soft countermeasures for a disaster, Journal of Natural Disaster Science 3 (1) (1981) 57-89.

[13] D. Rickenmann, M. Zimmermann, The 1987 debris flows in Switzerland: documentation and analysis, Geomorphology 8 (2) (1993) 175-189. doi:10.1016/0169-555X(93)90036-2.

[14] M. J. Bovis, M. Jakob, The role of debris supply conditions in predicting debris flow activity, Earth Surface Processes and Landforms 24 (11) (1999) 1039-1054. doi:10.1002/(SICI)1096-9837(199910)24:11;1039::AIDESP29;3.0.CO;2-U.

[15] D. Brayshaw, M. A. Hassan, Debris flow initiation and sediment recharge in gullies, Geomorphology 109 (3-4) (2009) 122-131. doi:10.1016/j.geomorph.2009.02.021.

[16] C. Tognacca, G. R. Bezzola, Debris-flow initiation by channel-bed failure, Debris-Flow Hazards Mitigations, Mechanics, Prediction, and Assessment (1997) 44-53. 
[17] S. H. Cannon, J. E. Gartner, M. G. Rupert, J. A. Michael, Emergency assessment of debris-flow hazards from basins burned by the Grand Prix and Old Fires of 2003, Southern California, Tech. Rep. 1072 (2004).

[18] M. Berti, A. Simoni, Experimental evidences and numerical modelling of debris flow initiated by channel runoff, Landslides 2 (3) (2005) 171-182. doi:10.1007/s10346-005-0062-4.

[19] C. Gregoretti, G. Dalla Fontana, The triggering of debris flow due to channel-bed failure in some alpine headwater basins of the Dolomites: Analyses of critical runoff, Hydrological Processes 22 (13) (2008) 2248-2263. doi:10.1002/hyp.6821.

[20] J. A. Coe, D. A. Kinner, J. W. Godt, Initiation conditions for debris flows generated by runoff at Chalk Cliffs, central Colorado, Geomorphology 96 (34) (2008) 270-297. doi:10.1016/j.geomorph.2007.03.017.

[21] W. Wu, R. C. Sidle, A Distributed Slope Stability Model for Steep Forested Basins, Water Resources Research 31 (8) (1995) 2097-2110. doi:10.1029/95WR01136.

[22] R. M. Iverson, M. E. Reid, R. G. Lahusen, Debris flow mobilization from landslides, Annual Review of Earth Planetary Science 25 (1997) 85-138. doi:10.1146/annurev.earth.25.1.85.

[23] M. E. Reid, R. G. LaHusen, R. M. Iverson, Debris-Flow Initiation Experiments Using Diverse Hydrologic Triggers, in: C. Cheng-Iung (Ed.), DebrisFlow Hazards Mitigation: Mechanics, Prediction and Assessment, American 
Society of Civil Engineers (ASCE), San Francisco, California, 1997, pp. 111.

[24] N. Lu, J. Godt, Infinite slope stability under steady unsaturated seepage conditions, Water Resources Research 44 (11) (2008) 1-13. doi:10.1029/2008WR006976.

[25] M. Cavalli, S. Trevisani, F. Comiti, L. Marchi, Geomorphometric assessment of spatial sediment connectivity in small Alpine catchments, Geomorphology 188 (2013) 31-41. doi:10.1016/j.geomorph.2012.05.007.

[26] N. Caine, The rainfall intensity - Duration control of shallow landslides and debris flows, Geografiska Annaler. Series A, Physical Geography 62 (1-2) (1980) 23-27.

[27] J. Innes, Debris flows, Progress in Physical Geography 7 (4) (1983) 469501. doi:10.1177/030913338300700401.

[28] M. Moser, F. Hohensinn, Geotechnical aspects of soil slips in Alpine regions, Engineering Geology 19 (3) (1983) 185-211. doi:https://doi.org/10.1016/0013-7952(83)90003-0.

[29] S. H. Cannon, S. Ellen, Rainfall conditions for abundant debris avalanches, San Francisco Bay region, California, California Geology 38 (12) (1985) $267-272$.

[30] R. C. Wilson, G. F. Wieczorek, Rainfall Thresholds for the Initiation of Debris Flows at La Honda, California, Environmental \& Engineering Geoscience I (1) (1995) 11-27. doi:https://doi.org/10.2113/gseegeosci.I.1.11. 
[31] P. Paronuzzi, A. Coccolo, G. Garlatti, Eventi meteorici critici e debris flow nei bacini montani del Friuli, L'acqua 6 (1) (1998) 39-50.

[32] A. M. Deganutti, L. Marchi, M. Arattano, Rainfall and debris-flow occurrence in the Moscardo basin (Italian Alps), in: G. F. Wieczorek, N. Naeser (Eds.), Debris flow Hazards Mitigation: Mechanics, Prediction, and Assessment; Proceedings of the 2nd International DFHM Conference, Taipei, Taiwan, 2000, pp. 67-72.

[33] G. Crosta, P. Frattini, Physically based distributed modelling for shallow landslide Hazard Zonation, in: Proceedings 3rd EGS Plinius Conference, Baja, Sardinia, Italy, 2001, pp. 463-487.

[34] M. Bacchini, A. Zannoni, Relations between rainfall and triggering of debris-flow: case study of Cancia (Dolomites, Northeastern Italy), Natural Hazards and Earth System Science 3 (1/2) (2003) 71-79. doi:10.5194/nhess3-71-2003.

[35] C. Gregoretti, G. Dalla Fontana, Rainfall threshold for the initiation of debris flows by channel-bed failure in the Dolomites, Debris-Flow Hazards Mitigation: Mechanics, Prediction, and Assesment (2007) 11-21.

[36] R. Pastorello, M. Hürlimann, V. D’Agostino, Correlation between the rainfall, sediment recharge, and triggering of torrential flows in the Rebaixader catchment (Pyrenees, Spain), Landslides 15 (10) (2018) 1921-1934. doi:10.1007/s10346-018-1000-6.

[37] C. Gregoretti, The initiation of debris flow at high slopes: Experi- 
mental results, Journal of Hydraulic Research 38 (2) (2000) 83-88. doi:10.1080/00221680009498343.

[38] C. Tognacca, G. R. Bezzola, H.-E. Minor, Threshold criterion for debris-flow initiation due to channel-bed failure, in: G. F. Wieczorek, Naeser (Eds.), Debris-Flow Hazards Mitigation: Mechanics, Prediction, and Assessment, 2000, pp. 89-97.

[39] G. Blasone, M. Cavalli, L. Marchi, F. Cazorzi, Monitoring sediment source areas in a debris-flow catchment using terrestrial laser scanning, Catena 123 (2014) 23-36. doi:10.1016/j.catena.2014.07.001.

[40] G. Bertoldi, V. D’Agostino, Colate detritiche: dinamiche degli apporti di sedimento a scala integrata di bacino, Phd thesis, University of Padova (2014).

[41] V. D’Agostino, M. Degetto, L. Marchi, D. Sonda, A. Vianello, Individuazione e definizione delle soluzioni tecnico-realizzative maggiormente idonee alla messa in sicurezza del torrente Rudan a ridosso dell'abitato di Vodo di Cadore (loc. Peaio)., Tech. rep., Associazione Italiana di Idronomia AIDI (2002).

[42] V. D’Agostino, Progetto $\mathrm{n}^{\circ}$ 647: Realizzazione di barriere fermaneve elastiche e di opere di miglioramento del deflusso idraulico, Comune di Livinallongo del Col di Lana (BL), Tech. rep., Servizio Forestale Regionale Veneto, Belluno (2003).

[43] C. Abancó, M. Hürlimann, J. Moya, M. Berenguer, Critical rainfall conditions for the initiation of torrential flows. Results from the Rebaixader 
catchment (Central Pyrenees), Journal of Hydrology 541 (2016) 218-229. doi:10.1016/j.jhydrol.2016.01.019.

[44] M. Hürlimann, C. Abancó, J. Moya, I. Vilajosana, Results and experiences gathered at the Rebaixader debris-flow monitoring site, Central Pyrenees, Spain, Landslides 11 (6) (2014) 939-953. doi:10.1007/s10346-013-0452-y.

[45] M. Hürlimann, C. Abancó, J. Moya, C. Raïmat, R. Luis-Fonseca, Debris-Flow Monitoring Stations in the Eastern Pyrenees. Description of Instrumentation, First Experiences and Preliminary Results, Italian Journal of Engineering Geology and Environment (2011) 553562doi:10.4408/IJEGE.2011-03.B-061.

[46] C. Abancó, M. Hürlimann, Estimate of the debris-flow entrainment using field and topographical data, Natural Hazards 71 (1) (2014) 363-383. doi:10.1007/s11069-013-0930-5.

[47] J. Whittaker, M. Jaggi, Blockschwellen, no. 91, Versuchsanstalt für Wasserbau, Hydrologie und Glaziologie, ETH, Zurich, Switzerland, 1986.

[48] M. Berti, R. Genevois, A. Simoni, P. R. Tecca, Field observations of a debris flow event in the Dolomites, Geomorphology 29 (3-4) (1999) 265-274.

[49] J. C. Bathurst, Flow Resistance Estimation in Mountain Rivers, Journal of Hydraulic Engineering 111 (4) (1985) 625-643.

[50] V. D’Agostino, T. Michelini, On kinematics and flow velocity prediction in step-pool channels, Water Resources Research 51 (2015) 4650-4667. doi:10.1002/2014WR016631. 
[51] Soil Conservation Service, National Engineering Handbook (NEH4), technical report, Tech. rep., U.S. Department of Agriculture, Washington D.C. (1972).

[52] R. H. Hawkins, T. J. Ward, E. Woodward, J. A. Van Mullem, Continuing evolution of rainfall-runoff and the curve number precedent, 2nd Joint Federal Interagency Conference (2010) 2-12.

[53] F. D’Asaro, G. Grillone, Empirical Investigation of Curve Number Method Parameters in the Mediterranean Area, Journal of Hydrologic Engineering 17 (10) (2012) 1141-1152. doi:10.1061/(ASCE)HE.1943-5584.0000570.

[54] D. Stewart, E. Canfield, R. Hawkins, Curve number determination methods and uncertainty in hydrologic soil groups from semiarid watershed data, Journal of Hydrologic Engineering 17 (11) (2011) 1180-1187.

[55] T. Lambe, R. Whitman, Soil Mechanics, John Wiley \& Sons, New York, 1968.

[56] F. Comiti, L. Marchi, P. Macconi, M. Arattano, G. Bertoldi, M. Borga, F. Brardinoni, M. Cavalli, V. D’Agostino, D. Penna, J. I. Theule, A new monitoring station for debris flows in the European Alps: first observations in the Gadria basin, Natural Hazards 73 (3) (2014) 1175-1198. doi:10.1007/s11069-014-1088-5.

[57] R. Genevois, P. R. Tecca, M. Berti, A. Simoni, Pore pressure distribution in the initiation area of a granular debris flow, in: E. Bromhead, N. Dixon, M. Ibsen (Eds.), Proceedings of the 8th International Symposium on Landslides, no. 12, Cardiff, UK, 2000, pp. 615-620. 
[58] J. A. Coe, S. H. Cannon, P. M. Santi, Introduction to the special issue on debris flows initiated by runoff, erosion, and sediment entrainment in western North America, Geomorphology 96 (2008) 247-249. doi:10.1016/j.geomorph.2007.05.001.

[59] L. Marchi, G. Dalla Fontana, M. Cavalli, F. Tagliavini, Rocky Headwaters in the Dolomites, Italy: Field Observations and Topographic Analysis, Arctic, Antarctic, and Alpine Research 40 (4) (2008) 685-694. doi:10.1657/15230430(07-037)[MARCHI]2.0.CO;2.

[60] F. Marra, E. I. Nikolopoulos, J. D. Creutin, M. Borga, Space-time organization of debris flows-triggering rainfall and its effect on the identification of the rainfall threshold relationship, Journal of Hydrology 541 (2016) 246255. doi:10.1016/j.jhydrol.2015.10.010.

[61] M. Hürlimann, C. Abancó, J. Moya, Rockfalls detached from a lateral moraine during spring season. 2010 and 2011 events observed at the Rebaixader debris-flow monitoring site (Central Pyrenees, Spain), Landslides 9 (3) (2012) 385-393. doi:10.1007/s10346-011-0314-4. 


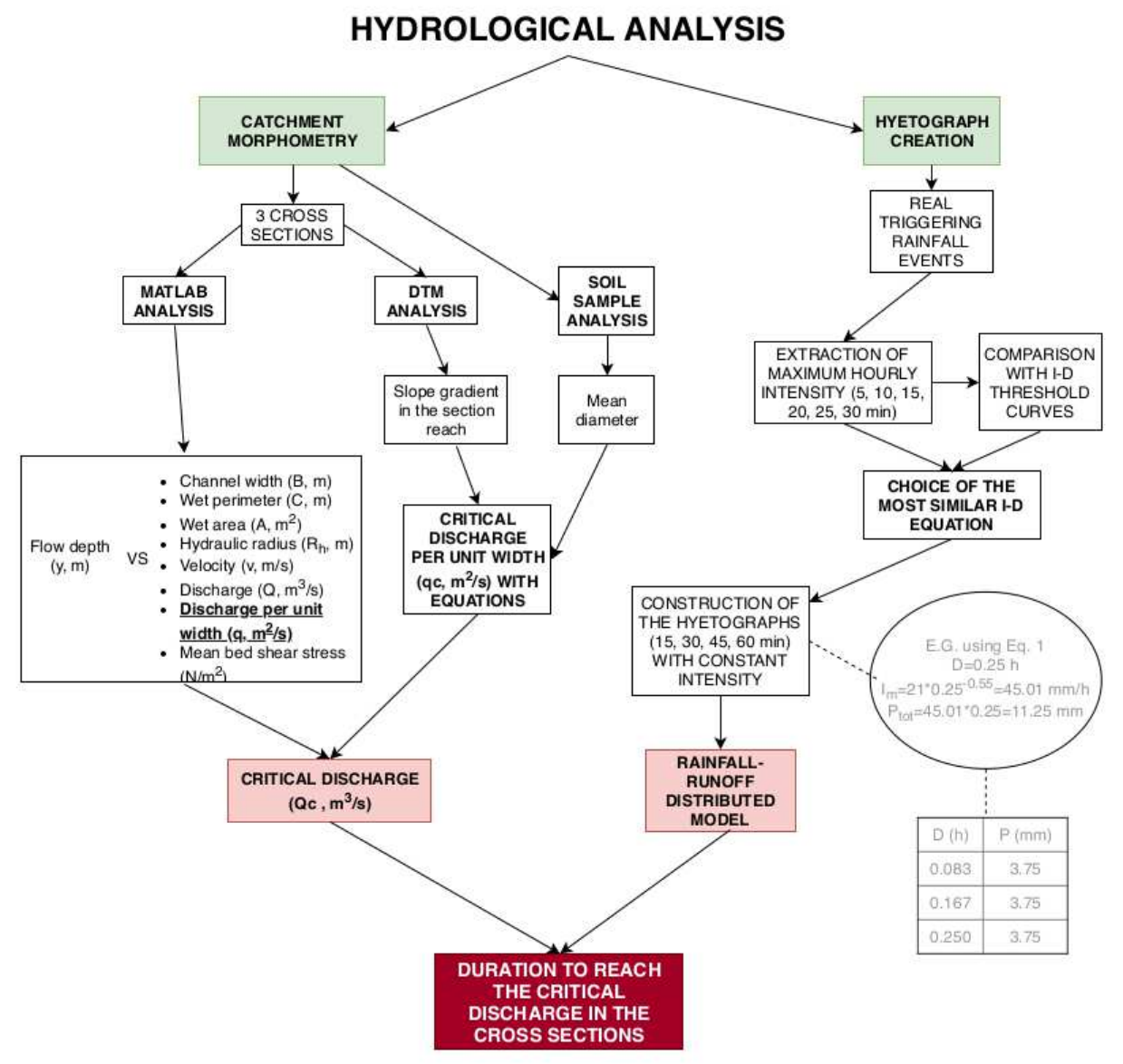

Figure 5: Flow chart of the methodological steps followed to perform the hydrological analysis. 


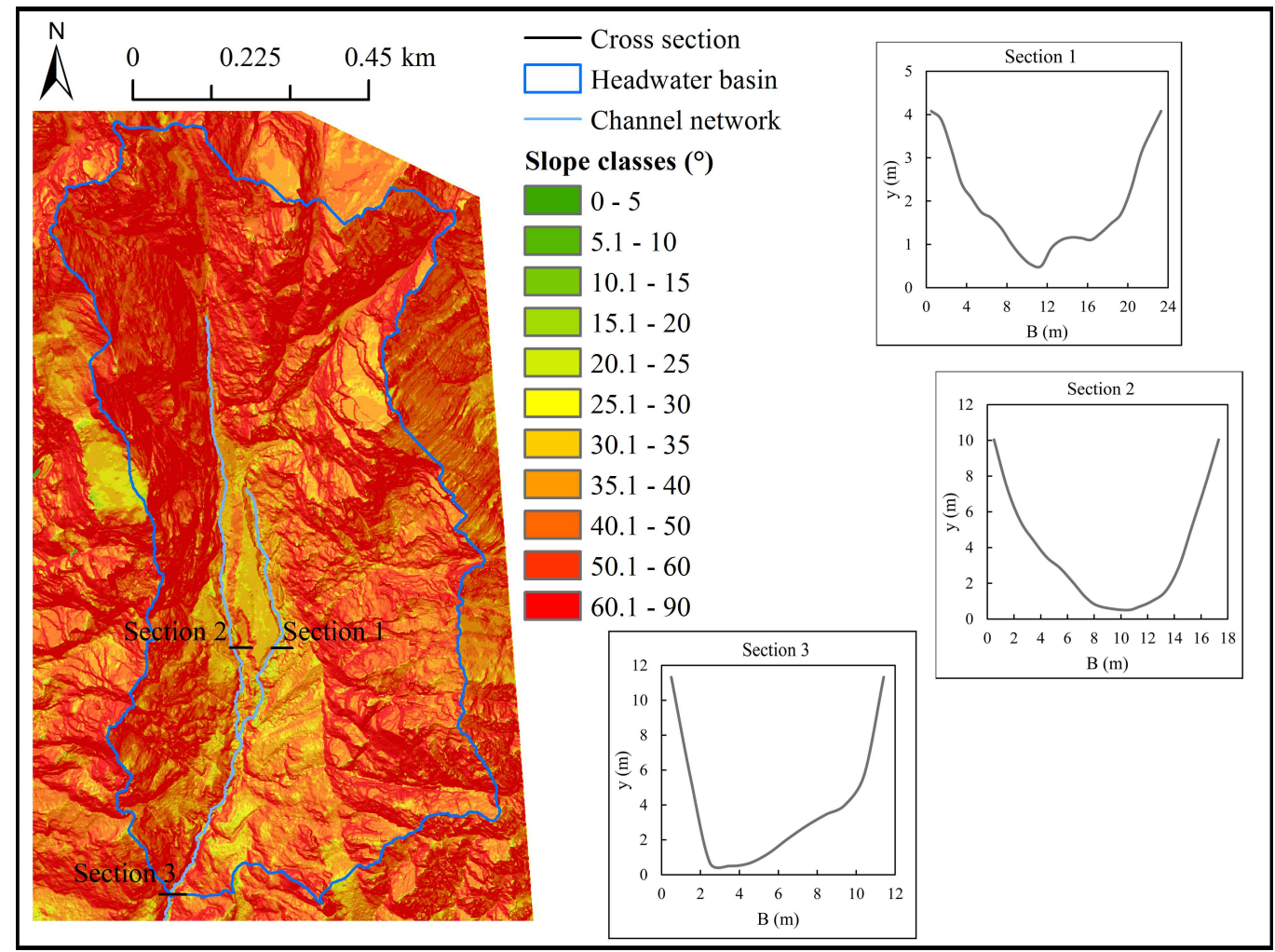

Figure 6: Location and shape of the three cross-sections of the Rudan hydrological modelling area. 


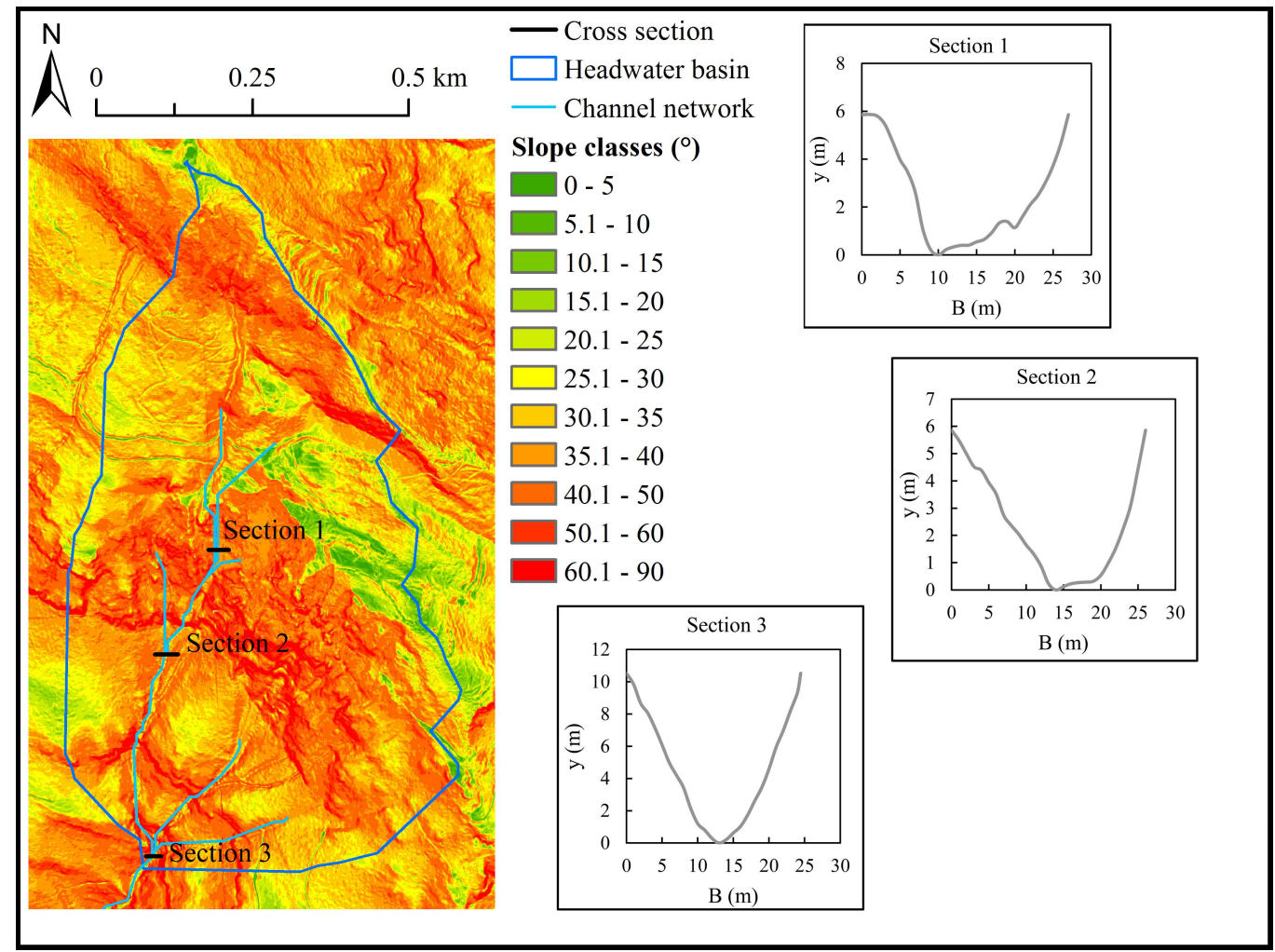

Figure 7: Location and shape of the three cross-sections of the Chiesa hydrological modelling area. 


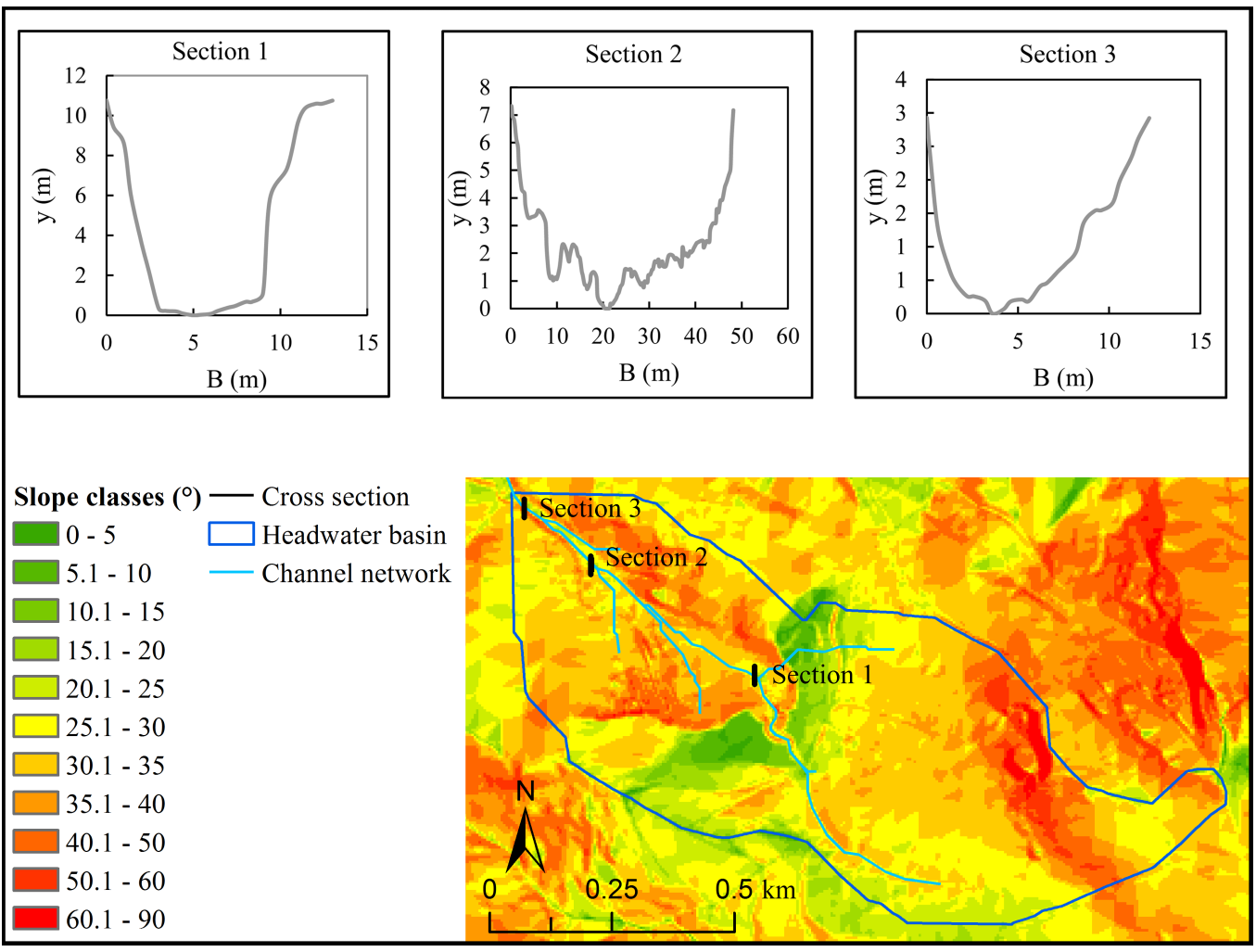

Figure 8: Location and shape of the three cross-sections of the Rebaixader hydrological modelling area. 

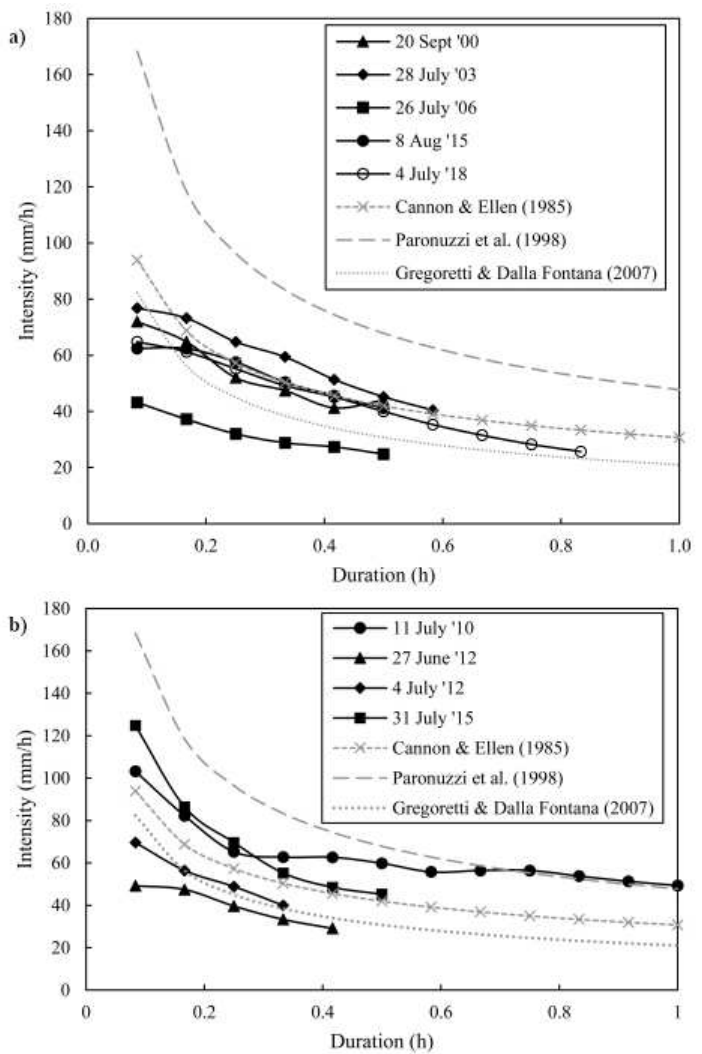

Figure 9: Comparison between the equations of [29], [31], [35] and: a) the five bursts that triggered debris flow in the Chiesa catchment; b) the four bursts that triggered debris flow in the Rebaixader catchment. 

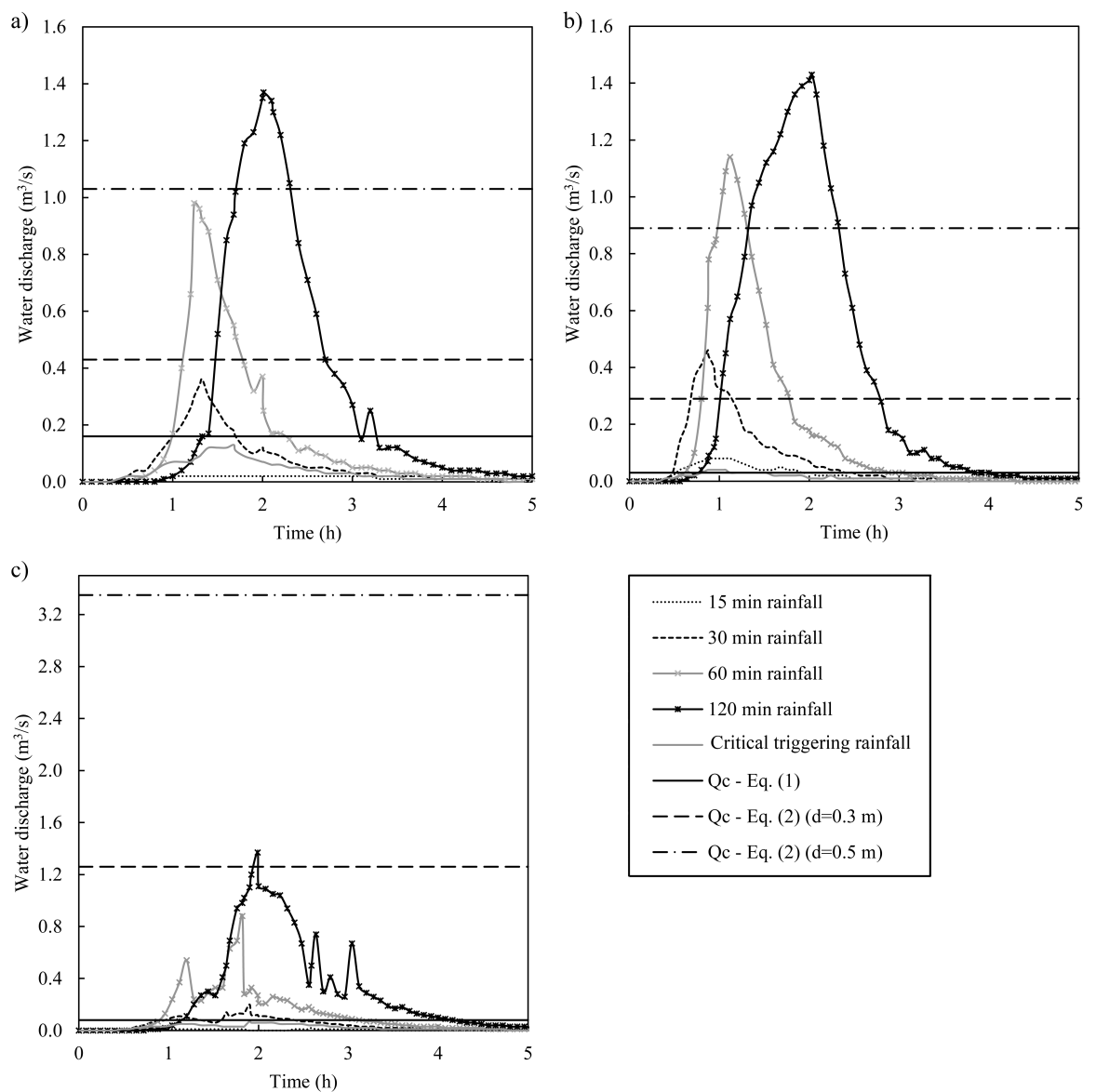

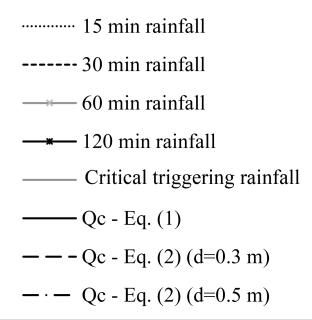

Figure 10: Hydrographs for the different simulated rainfall durations compared with the critical discharges for cross-section 3 of: a) Rudan, b) Chiesa, c) Rebaixader. 

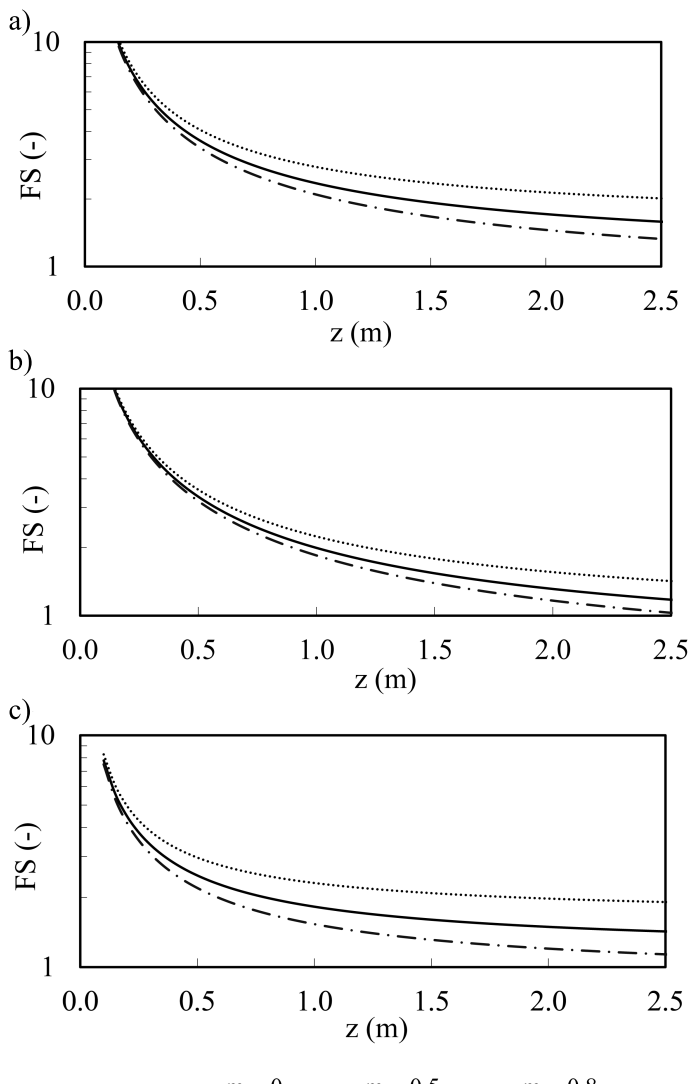

Figure 11: Stability factors for three possible water table height ( $m$ parameter in Eq. 7$)$ in: a) Rudan, b) Chiesa, c) Rebaixader. The stability limit is FS $=1$. 